Article

\title{
Structural Studies and Investigation on the Activity of Imidazole-Derived Thiosemicarbazones and Hydrazones against Crop-Related Fungi
}

\section{Débora C. Reis, Angel A. Recio Despaigne, Jeferson G. Da Silva, Nayane F. Silva, Camila F. Vilela,} Isolda C. Mendes, Jacqueline A. Takahashi and Heloisa Beraldo *

Departamento de Química, Universidade Federal de Minas Gerais, Belo Horizonte 31270-901, MG, Brazil

* Author to whom correspondence should be addressed; E-Mail: hberaldo@ufmg.br; Tel.: +55-31-3409-5740; Fax: +55-31-3409-5700.

Received: 14 August 2013; in revised form: 25 September 2013 / Accepted: 26 September 2013 / Published: 14 October 2013

\begin{abstract}
New imidazole derived thiosemicarbazones and hydrazones were prepared by condensation of 4(5)-imidazole carboxaldehyde, 4-(1H-imidazole-1-yl)benzaldehyde and 4-(1H-imidazole-1-yl)acetophenone with a thiosemicarbazide or hydrazide. All compounds were characterized by quantitative elemental analysis, IR and NMR techniques. Eight structures were determined by single crystal X-ray diffraction. The antifungal activities of the compounds were evaluated. None of the compounds exhibited significant activity against Aspergillus flavus and Candida albicans, while 4(5)-imidazolecarboxaldehyde thiosemicarbazone (ImT) and 4-(1H-imidazole-1-yl)benzaldehyde thiosemicabazone (4ImBzT) were highly and selectively active against Cladosporium cladosporioides. 4(5)-Imidazolecarboxaldehyde benzoyl hydrazone (4(5)ImPh), 4(5)-imidazolecarboxaldehydepara-chlorobenzoyl hydrazone (4(5) $\operatorname{Im} p \mathrm{ClPh}), 4(5)$-imidazolecarboxaldehyde-paranitrobenzoyl hydrazone (4(5) $\left.\operatorname{Im} p \mathrm{NO}_{2} \mathrm{Ph}\right)$, 4-(imidazole-1-yl)acetophenone-para-chlorobenzoyl hydrazone (4ImAcpClPh) and 4-(imidazole-1-yl)acetophenone-para-nitrobenzoylhydrazone $\left(4 \mathrm{ImAc} p \mathrm{NO}_{2} \mathrm{Ph}\right)$ were highly active against Candida glabrata. 4(5)Im $p C l P h$ and 4(5)Im $p \mathrm{NO}_{2} \mathrm{Ph}$ were very effective against $C$. cladosporioides. In many cases, activity was superior to that of the reference compound nystatin.
\end{abstract}

Keywords: imidazole; hydrazones; thiosemicarbazones; antifungal activity 


\section{Introduction}

The imidazole nucleus is well known to play an important role in living organisms since it is incorporated into the histidine molecule and many other important biological systems. Imidazole derivatives are the most used class of antifungal drugs [1], being active against pathogenic and nonpathogenic fungi [2]. Due to their antifungal properties imidazole-derived compounds have been used in agriculture as effective ingredients for controlling plants pests. Imidazole derivatives are employed in the control of spoilage microorganisms or organisms potentially harmful to man, in the protection of wood against fungi and also in food storage [3]. In addition, imidazole compounds were reported to be active against Fungi imperfecti, Basidiomycetes, Ascomycetes and Oomycetes. Outstanding activity was observed against powdery mildews (e.g., Erysiphenecator) and leaf spots (e.g., Mycosphaerella spp.). Furthermore, these compounds are effective against phytopathogenic gram-negative (e.g., Xanthomona spp., Pseudomonas spp., Erwinia amylovora, Ralstonia spp.) and gram-positive bacteria and viruses (e.g., tobacco mosaic virus) [4].

A. flavus is a worrying plant pathogen since it can produce aflatoxins on certain crops like oilseeds, corn and nuts (e.g., peanuts). Fungi unknown to produce aflatoxins can also cause agricultural damages, like $C$. cladosporioides that acts in the post-harvesting spoilage of fruits and vegetables. In vineyards, C. cladosporioides can also cause grape rot [5]. Both species have been reported to be among the major species normally found in several commodities like soybeans [6]. These species can become still more harmful since they can be spread by air from industrial food processing environments, such as grain mills or organic waste recycling facilities [7]. In contact with humans, they act as allergenic factors, causing a series of respiratory related diseases [8]. It has been reported that $C$. cladosporioides can play a role as opportunistic fungi causing ocular infections [9]. A. flavus has also been reported to be an opportunistic fungus especially in immuno-compromised patients [10].

Thiosemicarbazones [11,12] and hydrazones [13] are reported as compounds which present significant antifungal activity. Their metal complexes also exhibit antifungal properties [14-16]. Hydrazones have previously been reported as active against some species of Candida sp [16-18].

In the present work we synthesized a series of imidazole-derived thiosemicarbazones and hydrazones and tested the potential of these compounds as antifungal agents to fight $A$. flavus and $C$. cladosporioides. Since pathogens like Candida sp. have a huge importance as a clinical target of new fungicides, we extended the screening in order to evaluate the potential of the studied compounds against Candida albicans and Candida glabrata.

\section{Results and Discussion}

\subsection{Characterization of the Thiosemicarbazone Derivatives}

Eight imidazole-derived thiosemicarbazones (Figure 1) were obtained. Among them seven compounds (2-8) were original. Microanalyses were compatible with the proposed formulations. The infrared spectra of the thiosemicarbazones showed a very strong band at 3,446-3,145 $\mathrm{cm}^{-1}$ which was attributed to the $v(\mathrm{~N}-\mathrm{H})$ vibration. The $v(\mathrm{C}=\mathrm{N})$ and $\mathrm{v}(\mathrm{C}=\mathrm{S})$ vibrations appeared at $1,638-1,601 \mathrm{~cm}^{-1}$ and $848-830 \mathrm{~cm}^{-1}$, respectively $[19,20]$. 
Figure 1. Generic representation for imidazole-derived thiosemicarbazones.
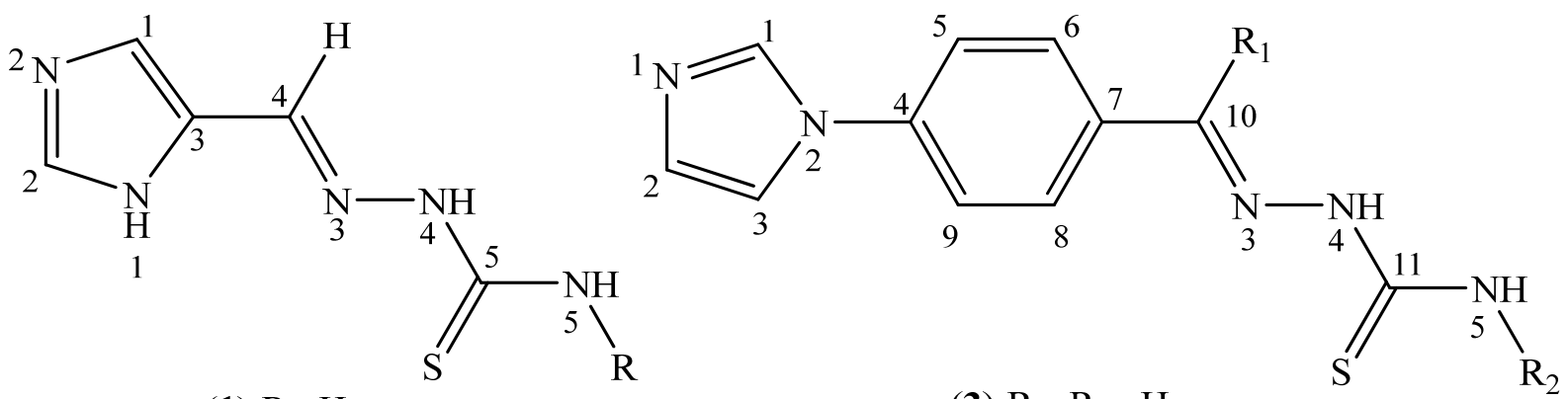

$$
\begin{aligned}
& \text { (1) }-\mathrm{R}=\mathrm{H} \\
& \text { (2) }-\mathrm{R}=\mathrm{C}_{6} \mathrm{H}_{5}
\end{aligned}
$$$$
\text { (3) }-\mathrm{R}_{1}=\mathrm{R}_{2}=\mathrm{H}
$$$$
\text { (4) }-\mathrm{R}_{1}=\mathrm{H} ; \mathrm{R}_{2}=\mathrm{CH}_{3}
$$$$
\text { (5) }-\mathrm{R}_{1}=\mathrm{H} ; \mathrm{R}_{2}=\mathrm{C}_{6} \mathrm{H}_{5}
$$$$
\text { (6) }-\mathrm{R}_{1}=\mathrm{CH}_{3} ; \mathrm{R}_{2}=\mathrm{H}
$$$$
\text { (7) }-\mathrm{R}_{1}=\mathrm{R}_{2}=\mathrm{CH}_{3}
$$$$
\text { (8) }-\mathrm{R}_{1}=\mathrm{CH}_{3} ; \mathrm{R}_{2}=\mathrm{C}_{6} \mathrm{H}_{5}
$$

The NMR spectra of all thiosemicarbazones were recorded in DMSO- $d_{6}$. The ${ }^{1} \mathrm{H}$ resonances were assigned on the basis of chemical shifts and multiplicities. The carbon type $(\mathrm{C}, \mathrm{CH})$ was determined by using distortionless enhancement by polarization transfer (DEPT 135) experiments. The assignments of the protonated carbons were made by 2D hetero-nuclear multiple quantum coherence experiments (HMQC).

In the ${ }^{1} \mathrm{H}$ - and ${ }^{13} \mathrm{C}$-NMR spectra of thiosemicarbazone $\mathbf{1}$ duplicated signals were observed for all hydrogens and carbons, indicating the presence of the $Z(60 \%)$ and $E(40 \%)$ configurational isomers in the DMSO- $d_{6}$ solution, as frequently occurs with thiosemicarbazones [21]. In the spectra of 2 three signals were observed for each hydrogen and each carbon. In the ${ }^{13} \mathrm{C}-\mathrm{NMR}$ the signals at $\delta 175.29$ and $\delta 175.47$ were assigned to $\mathrm{C}=\mathrm{S}$ of the $E$ and $Z$ isomers, respectively, and the signal at $\delta 172.05$ to $\mathrm{C}-\mathrm{SH}$. The proportion of $E$ and $Z$ isomers is 1:1, but it was not possible to determine the percentage of the thiol form in solution due to overlapping signals in the $\mathrm{S}-\mathrm{H}$ spectral region. The thione-thiol tautomerism had been previously observed for other thiosemicarbazones [22].

In the ${ }^{1} \mathrm{H}$ - and ${ }^{13} \mathrm{C}-\mathrm{NMR}$ spectra of 3-8 only one signal was observed for each hydrogen and carbon; the chemical shifts indicate the presence of only the $\mathrm{E}$ isomer in solution. Generally when $\mathrm{N} 5-\mathrm{Hb}$ is replaced by a methyl or a phenyl group in 4, 5, 7 and 8 the signal of N5-Ha shifts upfield. For both formyl and acetyl compounds the signals of the imidazole and benzene rings were observed in the same region.

The N4-H signals at $\delta 11.93-11.53$ (formyl derivatives) and $\delta 10.66-10.27$ (acetyl derivatives) indicate hydrogen bonding with the solvent [21]. In the spectra of the acetyl derivatives the signals of N4-H appear at lower frequencies due to the gamma-gauche effect of the $\mathrm{CH}_{3}$ group in $\mathrm{C} 10$, which makes more difficult the interaction of DMSO- $d_{6}$ with N4-H [23].

Crystals suitable for X-ray diffraction studies were obtained by slow evaporation from the mother liquor in the synthesis of $\mathbf{1}, \mathbf{2}, \mathbf{3}, \mathbf{4}$ and $\mathbf{5}$. Interestingly, $\mathbf{1}$ crystallized with one water molecule as $\operatorname{ImT} \cdot \mathrm{H}_{2} \mathrm{O}$ (1a). The crystal data and refinement results for imidazole-derived thiosemicarbazones are given in Table S1 of the Supplementary Material. The ORTEP diagrams for 1a and 2-5 and the 
numbering scheme are shown in Figure 2. Selected bonds distances and angles are listed in Table S2. The geometric parameters for hydrogen bonds in 1a and 2-5 are listed in Table 1.

Compounds 1a, 2, 3 and 5 crystallized in the monoclinic system with one molecule of the thiosemicarbazone per asymmetric unit, while $\mathbf{4}$ crystallized in the triclinic system with two molecules per asymmetric unit (see Figure 2). In all structures the CNNC(S)N backbone is almost planar with rms distance of atoms from the least-squares plane of $0.0277 \AA$ (1a), $0.0137 \AA$ (2), $0.0705 \AA$ (3), 0.0438 and $0.0669 \AA$ (for C10N3N4C11S1N5 and C30N23N24C31S21N25, respectively, in 4) and $0.0311 \AA(5)$. The bond lengths in the thiosemicarbazone backbone are similar to those previously described in the literature $[19,20,24,25]$.

Figure 2. Molecular plots of $\operatorname{ImT} \cdot \mathrm{H}_{2} \mathrm{O}$ (1a), $\operatorname{ImTPh}(\mathbf{2}), 4 \operatorname{ImBzT}(\mathbf{3}), 4 \operatorname{ImBzTM}(4)$ and $4 \mathrm{ImBzTPh}(\mathbf{5})$, showing the labeling scheme of the non-H atoms and their displacement ellipsoids at the $50 \%$ probability level.
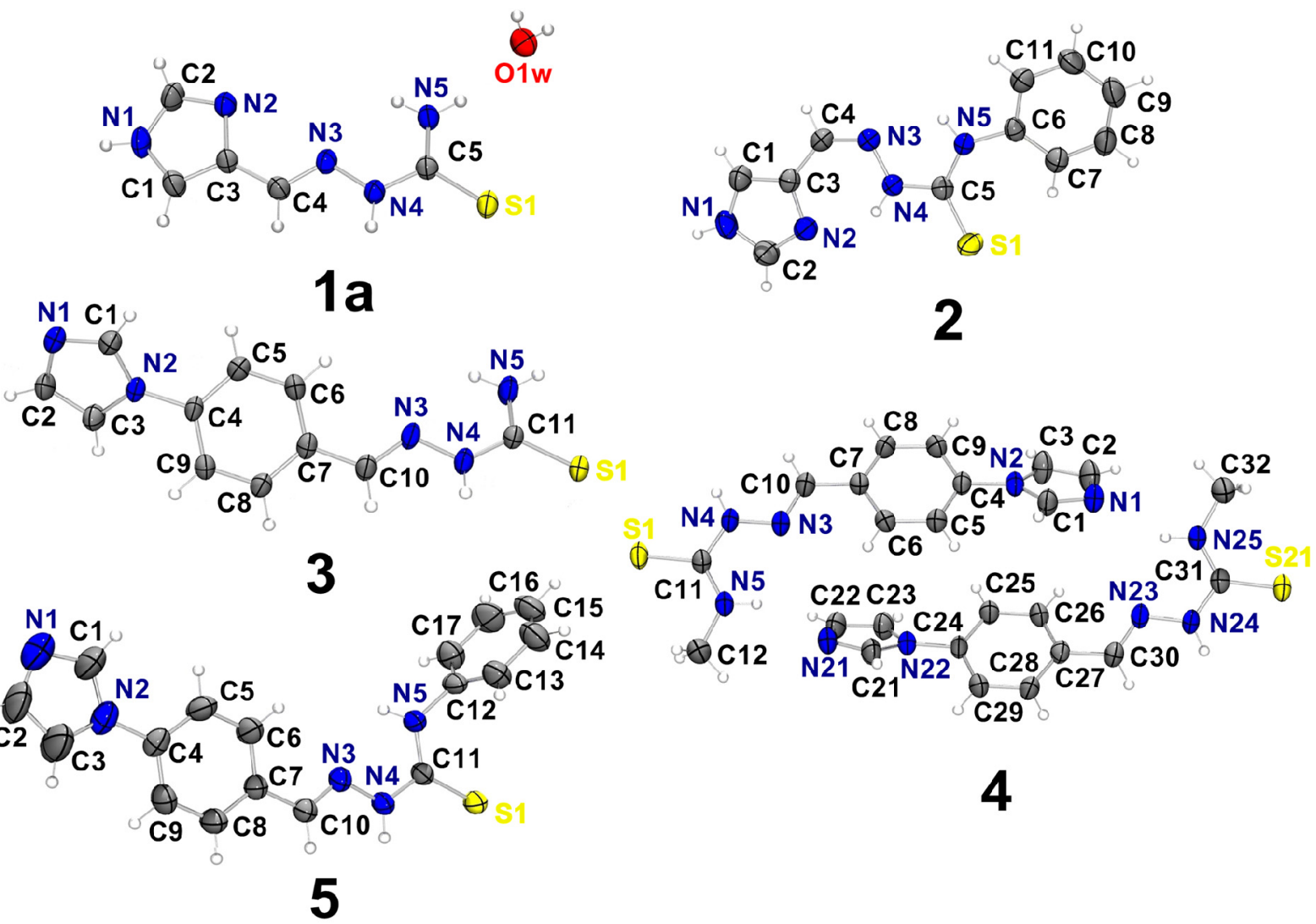

The thiosemicarbazone backbone of 1a and 3-5 adopt the EE conformation in relation to the $\mathrm{C} 4-\mathrm{N} 3$ or $\mathrm{C} 10-\mathrm{N} 3$ and $\mathrm{N} 4-\mathrm{C} 5$ or $\mathrm{N} 4-\mathrm{C} 11$ bonds. The N5-H..N3 hydrogen bond probably hinders rotation around the $\mathrm{N} 4-\mathrm{C} 5$ or $\mathrm{N} 4-\mathrm{C} 11$ bonds and might contribute to the stability of the $E$ conformation. In fact, the $E E$ conformation is commonly observed in 2-formylpyridine- and 2-acetylpyridine-derived thiosemicarbazones in the solid state [26,27]. Furthermore, the $E E$ conformation allows the formation of dimmers via intermolecular N4-H..S1 hydrogen bonds (see Table 1). In addition, in the case of 1a a hydration water molecule forms intermolecular hydrogen bonds (see Table 1). 
Table 1. Hydrogen bonds geometric parameters $\left(\AA,^{\circ}\right)$ for $\operatorname{ImT} \cdot \mathrm{H}_{2} \mathrm{O}(\mathbf{1 a}), \operatorname{ImTPh}(\mathbf{2})$, 4ImBzT (3), 4ImBzTM (4) and $4 \operatorname{ImBzTPh}(5)$.

\begin{tabular}{|c|c|c|c|c|}
\hline D-H...A & $\mathrm{d}(\mathrm{D}-\mathrm{H})$ & $\mathrm{d}(\mathbf{H} \cdots \mathbf{A})$ & $d(D \cdots A)$ & $<$ (DHA) \\
\hline \multicolumn{5}{|c|}{$1 \mathrm{a}$} \\
\hline $\mathrm{O} 1 \mathrm{~W}-\mathrm{H} 1 \mathrm{~W} \cdots \mathrm{N} 2^{\mathrm{i}}$ & $0.8599(10)$ & $2.158(10)$ & $2.950(2)$ & $153(2)$ \\
\hline $\mathrm{O} 1 \mathrm{~W}-\mathrm{H} 2 \mathrm{~W} \cdots \mathrm{N} 2{ }^{\mathrm{ii}}$ & $0.8599(10)$ & $2.200(5)$ & $3.0487(19)$ & $169(2)$ \\
\hline $\mathrm{N} 1-\mathrm{H} 1 \cdots \mathrm{S} 1{ }^{\mathrm{iii}}$ & 0.86 & 2.58 & $3.3540(15)$ & 149.6 \\
\hline $\mathrm{N} 4-\mathrm{H} 4 \mathrm{~A} \cdots \mathrm{S} 1{ }^{\text {iv }}$ & 0.86 & 2.61 & $3.4168(14)$ & 157.2 \\
\hline $\mathrm{N} 5-\mathrm{H} 5 \mathrm{~A} \cdots \mathrm{O} 1 \mathrm{~W}^{\mathrm{ii}}$ & 0.86 & 2.46 & $3.2804(19)$ & 161.0 \\
\hline 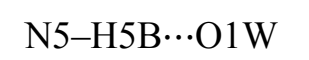 & 0.86 & 2.11 & $2.9429(19)$ & 164.2 \\
\hline \multicolumn{5}{|c|}{2} \\
\hline $\mathrm{N} 1-\mathrm{H} 1 \cdots \mathrm{S} 1^{\mathrm{v}}$ & 0.86 & 2.61 & $3.3632(14)$ & 147.1 \\
\hline $\mathrm{N} 4-\mathrm{H} 4 \cdots \mathrm{N} 2$ & 0.86 & 2.02 & $2.7158(18)$ & 137.2 \\
\hline 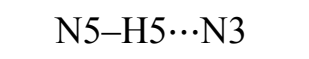 & 0.86 & 2.12 & $2.5866(17)$ & 113.9 \\
\hline \multicolumn{5}{|c|}{3} \\
\hline $\mathrm{N} 4-\mathrm{H} 4 \cdots \mathrm{S} 1$ vi & 0.86 & 2.60 & $3.4424(13)$ & 166.4 \\
\hline N5-H5A $\cdots$ S1 $1^{\text {vii }}$ & 0.86 & 2.79 & $3.4162(14)$ & 130.6 \\
\hline $\mathrm{N} 5-\mathrm{H} 5 \mathrm{~B} \cdots \mathrm{N} 1{ }^{\text {viii }}$ & 0.86 & 2.12 & $2.9405(18)$ & 159.4 \\
\hline \multicolumn{5}{|c|}{4} \\
\hline $\mathrm{N} 24-\mathrm{H} 2 \cdots \mathrm{S} 1^{\text {ix }}$ & 0.86 & 2.56 & $3.3890(18)$ & 162.7 \\
\hline $\mathrm{N} 25-\mathrm{H} 25 \mathrm{~A} \cdots \mathrm{N} 9$ & 0.86 & 2.22 & $2.999(2)$ & 150.9 \\
\hline $\mathrm{N} 4-\mathrm{H} 4 \cdots \mathrm{S} 21^{\mathrm{x}}$ & 0.86 & 2.55 & $3.3501(19)$ & 154.8 \\
\hline N5-H5A $\cdots$ N21 & 0.86 & 2.21 & $2.984(2)$ & 149.2 \\
\hline \multicolumn{5}{|c|}{5} \\
\hline $\mathrm{N} 4-\mathrm{H} 4 \cdots \mathrm{S} 1^{\mathrm{xi}}$ & 0.86 & 2.56 & $3.3950(17)$ & 164.0 \\
\hline $\mathrm{N} 5-\mathrm{H} 5 \cdots \mathrm{N} 1{ }^{\mathrm{xii}}$ & 0.86 & 2.61 & $3.309(3)$ & 139.1 \\
\hline
\end{tabular}

Symmetry transformations used to generate equivalent atoms: $i=-x+1, y+1 / 2,-z+1 / 2 ; i i=-x+1,-y+1$, $-\mathrm{z}+1 ;$ iii $=\mathrm{x}, \mathrm{y}-1, \mathrm{z} ;$ iv $=-\mathrm{x},-\mathrm{y}+1,-\mathrm{z} ; \mathrm{v}=-\mathrm{x}+2, \mathrm{y}-1 / 2,-\mathrm{z}+3 / 2 ; \mathrm{vi}=-\mathrm{x}+2,-\mathrm{y},-\mathrm{z}+2$; vii $=x,-y+1 / 2, z+1 / 2 ;$ viii $=x-1,-y+1 / 2, z-3 / 2 ; i x=x, y, z-1 ; x=x, y, z+1 ; x i=-x+1,-y+2,-z+1$ and $\mathrm{xii}=-\mathrm{x}+2,-\mathrm{y},-\mathrm{z}+1$.

In contrast, 2 adopts the $Z E$ conformation in relation to the C4-N3 and N4-C5 bonds (see Figure 2). This probably occurs due to the presence of a weak N1-H $\cdots \mathrm{N} 3$ hydrogen bond (see Table 1). This conformation is often observed in 2-benzoylpyridine-derived thiosemicarbazones [28].

\subsection{Characterization of the Hydrazone Derivatives}

Twelve new imidazole-derived hydrazones (Figure 3) were obtained. Microanalyses were compatible with the proposed formulations. In the infrared spectra of the hydrazones the absorption at $3,240-3,139 \mathrm{~cm}^{-1}$ was attributed to the $v(\mathrm{~N}-\mathrm{H})$ vibration mode. Absorptions at $3,100-3,020 \mathrm{~cm}^{-1}$ in the


$1,687-1,659 \mathrm{~cm}^{-1}$ were assigned to $\mathrm{v}(\mathrm{C}=\mathrm{O})$ and absorptions at $1,626-1,606 \mathrm{~cm}^{-1}$ were attributed to $\mathrm{v}(\mathrm{C}=\mathrm{N})$. 
Figure 3. Generic representation for imidazole-derived hydrazones.
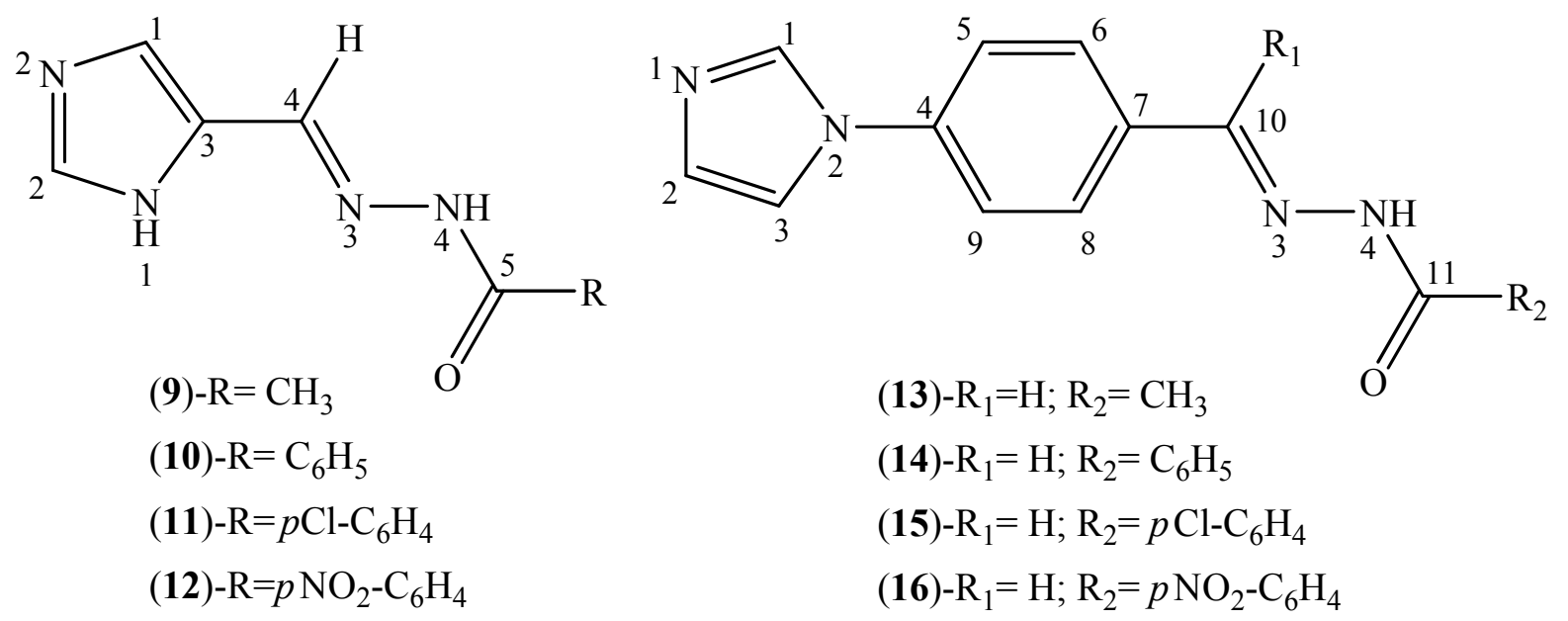

(14) $-\mathrm{R}_{1}=\mathrm{H} ; \mathrm{R}_{2}=\mathrm{C}_{6} \mathrm{H}_{5}$

(15) $-\mathrm{R}_{1}=\mathrm{H} ; \mathrm{R}_{2}=p \mathrm{Cl}-\mathrm{C}_{6} \mathrm{H}_{4}$

(16) $-\mathrm{R}_{1}=\mathrm{H} ; \mathrm{R}_{2}=p \mathrm{NO}_{2}-\mathrm{C}_{6} \mathrm{H}_{4}$

(17) $-\mathrm{R}_{1}=\mathrm{R}_{2}=\mathrm{CH}_{3}$

(18) $-\mathrm{R}_{1}=\mathrm{CH}_{3} ; \mathrm{R}_{2}=\mathrm{C}_{6} \mathrm{H}_{5}$

(19) $-\mathrm{R}_{1}=\mathrm{CH}_{3} ; \mathrm{R}_{2}=p \mathrm{Cl}-\mathrm{C}_{6} \mathrm{H}_{4}$

(20) $-\mathrm{R}_{1}=\mathrm{CH}_{3} ; \mathrm{R}_{2}=p \mathrm{NO}_{2}-\mathrm{C}_{6} \mathrm{H}_{4}$

As for the thiosemicarbazones the NMR spectra of all hydrazones were recorded in DMSO- $d_{6}$. Three signals for all hydrogens and carbons were found in the ${ }^{1} \mathrm{H}$ - and ${ }^{13} \mathrm{C}-\mathrm{NMR}$ spectra of compound $\mathbf{9}$, suggesting the existence of three isomers in solution. The signals of C5 at $\delta 171.89$ and $\delta 171.57$ were attributed to $\mathrm{C}=\mathrm{O}$ of the $E$ and $Z$ isomers, respectively, and the signal at $\delta 168.35$ was assigned to $\mathrm{C}-\mathrm{OH}$ in the enol tautomer [29].

The signals at $\delta 11.22, \delta 11.03$ and $\delta 9.76$ were attributed to $\mathrm{N} 1-\mathrm{H}$ of the imidazole ring in the enol, $E$ and $Z$ isomers, respectively. Signals at $\delta 13.30$ and $\delta 12.93$ were assigned to $\mathrm{N} 4-\mathrm{H}$ in the $Z$ and $E$ isomers. The $\mathrm{O}-\mathrm{H}$ signal of the enol tautomer is overlapped with the $\mathrm{N} 4-\mathrm{H}$ signal of the $E$ isomeric form.

In the ${ }^{1} \mathrm{H}-\mathrm{NMR}$ spectra of compounds 10-12 only one signal was observed for each hydrogen. The signals attributed to $\mathrm{N} 1-\mathrm{H}$ were found at $\delta 8.38(\mathbf{1 0}), \delta 8.39(\mathbf{1 1})$ and $\delta 8.37(\mathbf{1 2})$ and those of $\mathrm{N} 4-\mathrm{H}$ were found at $\delta 14.29(\mathbf{1 0}), \delta 14.34$ (11) and $\delta 14.54$ (12), indicating that they are in the $Z$ configuration in solution. In the ${ }^{13} \mathrm{C}-\mathrm{NMR}$ spectra of $\mathbf{1 0}$ and $\mathbf{1 1}$ one signal was verified for each carbon, confirming the existence of only one isomer in solution. The signals of $\mathrm{C} 5=\mathrm{O}$ were observed at $\delta 162.81$ and $\delta 162.26$ in the spectra of $\mathbf{1 0}$ and 11, respectively. Due to the low solubility of $\mathbf{1 2}$ it was impossible to record its ${ }^{13} \mathrm{C}$-NMR spectrum.

The ${ }^{1} \mathrm{H}$ and ${ }^{13} \mathrm{C}$-NMR spectra of compounds $\mathbf{1 3}$ and $\mathbf{1 7}$ showed duplicated signals for each hydrogen and carbon indicating the presence of two isomeric forms in solution. The signals at $\delta 172.00$ and $\delta 165.67$ for 13 and $\delta 171.82$ and $\delta 166.13$ for 17 corresponded to $\mathrm{C} 11=\mathrm{O}$ and $\mathrm{C} 11-\mathrm{OH}$ of the keto and enol tautomers, respectively [29]. The signals at $\delta 11.49$ and $\delta 10.51$ were attributed to N4-H in the keto tautomer for $\mathbf{1 3}$ and $\mathbf{1 7}$, and those at $\delta 11.35$ and $\delta 10.41$ to $\mathrm{O}-\mathrm{H}$ in the enol tautomer, respectively. The keto tautomers adopt the $E$ configuration in solution.

In the spectra of compounds 14-16, 18 and 19, only one signal was observed for each hydrogen and carbon. The signals of $\mathrm{N} 4-\mathrm{H}$ appear at $\delta 12.22-10.84$, indicating the presence of $E$ configuration for these compounds in solution. The signal at $\delta$ 163.82-161.13 for 14-16 and the signal at $\delta 166.13$ and $\delta$ 
171.82 for $\mathbf{1 8}$ and $\mathbf{1 9}$ were assigned to $\mathrm{C} 11=\mathrm{O}$. Due to the low solubility of compound $\mathbf{2 0}$ it was impossible to record its NMR spectrum.

Crystals were obtained by slow evaporation from the mother liquor in the synthesis of 11, 14 and 15. Interestingly, 11 crystallized with one hydration water molecule as $4(5) \operatorname{Im} p \mathrm{ClPh} \cdot \mathrm{H}_{2} \mathrm{O}$ (11a). The crystal data and refinement results for the imidazole-derived hydrazones are given in Table S3 of the Supplementary Material. The ORTEP diagrams for 11a, 14 and 15 and the numbering scheme are shown in Figure 4. The selected bonds and angles are listed in Table S4. The geometric parameters for hydrogen bonds in 11a, $\mathbf{1 4}$ and $\mathbf{1 5}$ are listed in Table 2.

The three compounds crystallized in the monoclinic system with one molecule of the hydrazone per asymmetric unit (see Figure 4). In all structures the $\mathrm{CNNC}(\mathrm{O}) \mathrm{C}$ backbone is almost planar with $r m s$ distance of atoms from the least-squares plane of $0.0402 \AA$ (11a), $0,0476 \AA$ (14) and $0.0287 \AA$ (15).

Figure 4. Molecular plots of $4(5) \operatorname{Im} p C l P h \cdot \mathrm{H}_{2} \mathrm{O}($ 11a), $4 \operatorname{ImBz} \mathrm{Ph}(14)$ and $4 \operatorname{ImBz} p \mathrm{ClPh}$ (15), showing the labeling scheme of the non-H atoms and their displacement ellipsoids at the $50 \%$ probability level.

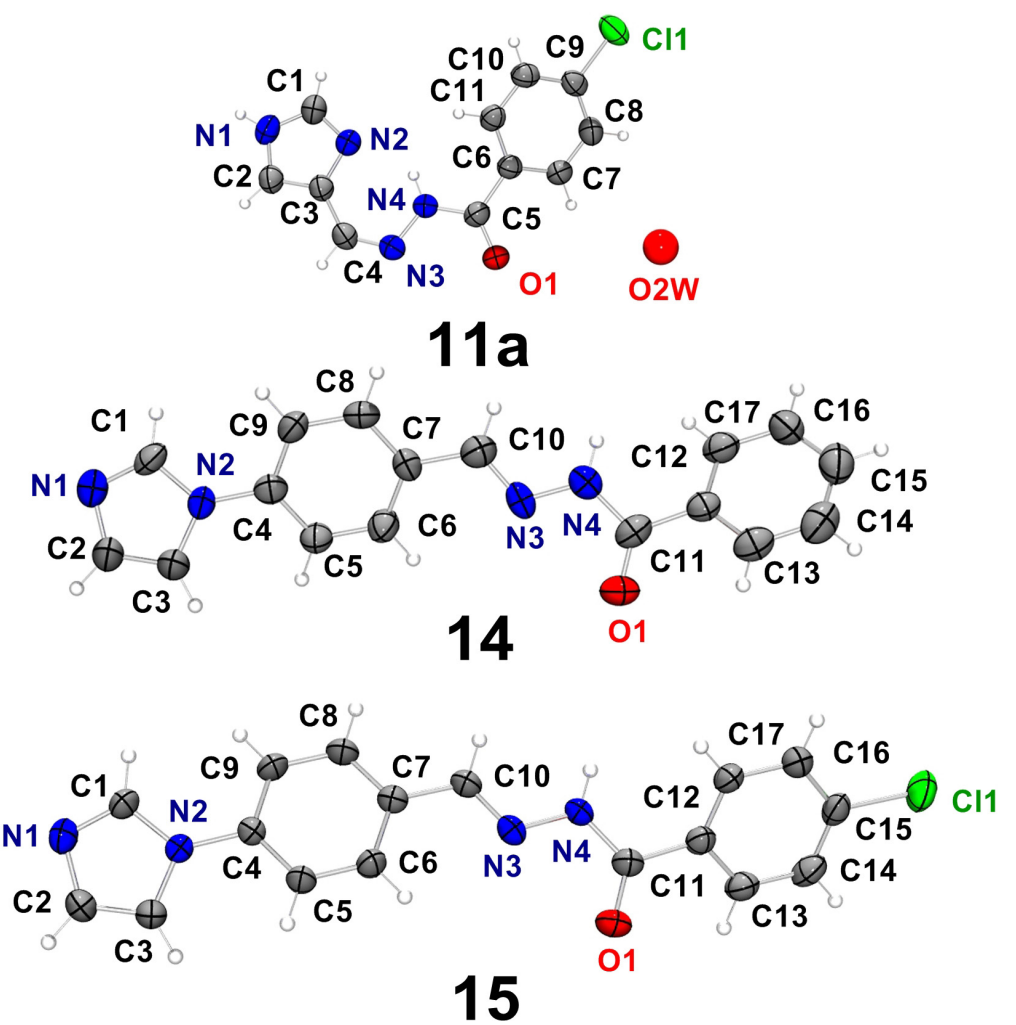

The hydrazone backbone of 11a adopts the $Z Z$ conformation in relation to the C4-N3 and N4-C5 bonds. The intramolecular $\mathrm{N} 4-\mathrm{H} \cdots \mathrm{N} 2$ hydrogen bond probably hinders rotation around $\mathrm{C} 4-\mathrm{N} 3$ contributing to the stability of the $Z$ configuration. This conformation was also observed by us in 2-benzoylpyridine-derived hydrazones [30]. The crystal packing of $11 \mathbf{a}$ is dominated by $\mathrm{N}-\mathrm{H} \cdots \mathrm{N}$ and $\mathrm{N}-\mathrm{H}$... O hydrogen bonds (see Table 2).

In contrast, 14 and $\mathbf{1 5}$ adopt the EZ conformation in relation to the C10-N3 and N4-C11 bonds. The crystal packings of $\mathbf{1 4}$ and $\mathbf{1 5}$ are very similar and are dominated by intermolecular N4-H..N1 hydrogen bond (see Table 2). 
Table 2. Hydrogen bonds geometric parameters $\left(\AA,^{\circ}\right)$ of for $4(5) \operatorname{Im} p \mathrm{ClPh} \cdot \mathrm{H}_{2} \mathrm{O}(11 \mathbf{a})$, $4 \operatorname{ImBzPh}(\mathbf{1 4})$ and $4 \operatorname{ImBzp} \mathrm{ClPh}(\mathbf{1 5})$.

\begin{tabular}{|c|c|c|c|c|}
\hline D-H...A & $\mathrm{d}(\mathrm{D}-\mathrm{H})$ & $d(H \cdots A)$ & $d(D \cdots A)$ & $<$ (DHA) \\
\hline \multicolumn{5}{|c|}{$1 \mathbf{a}$} \\
\hline $\mathrm{N} 1-\mathrm{H} 1 \mathrm{~A} \cdots \mathrm{O} 1^{\mathrm{i}}$ & 0.86 & 1.96 & $2.799(5)$ & 164.4 \\
\hline $\mathrm{N} 1-\mathrm{H} 1 \mathrm{~A} \cdots \mathrm{N} 3^{\mathrm{i}}$ & 0.86 & 2.67 & $3.242(5)$ & 125.4 \\
\hline $\mathrm{N} 4-\mathrm{H} 4 \mathrm{~A} \cdots \mathrm{N} 2$ & 0.86 & 2.00 & $2.698(5)$ & 137.0 \\
\hline \multicolumn{5}{|c|}{14} \\
\hline $\mathrm{N} 4-\mathrm{H} 4 \cdots \mathrm{N} 1^{\mathrm{ii}}$ & 0.86 & 2.26 & $3.079(3)$ & 158.8 \\
\hline \multicolumn{5}{|c|}{15} \\
\hline $\mathrm{N} 4-\mathrm{H} 4 \cdots \mathrm{N} 1{ }^{\text {ii }}$ & 0.86 & 2.30 & $3.1411(16)$ & 166.9 \\
\hline
\end{tabular}

Symmetry transformations used to generate equivalent atoms: $i=-x+112, y-1 / 2,-z+3 / 2$ and ii $=x-1$, $-y+1 / 2, z+1 / 2$.

\subsection{Antifungal Activity}

The results of the biological assays are reported in Table 3. In general, the thiosemicarbazones presented lower activity than the hydrazones. However, high activity was found for thiosemicarbazones 1 and 3 against $C$. cladosporioides, with $\mathrm{MIC}_{50}=5.79$ and $2.00 \mu \mathrm{M}$, respectively. These values were significantly lower than those determined for nystatin $\left(\mathrm{MIC}_{50}=269 \mu \mathrm{M}\right)$ which was used as positive control. Compounds $\mathbf{1}$ and $\mathbf{3}$ were selectively active against $C$. cladosporioides, since their $\mathrm{MIC}_{50}$ values against A. flavus, C. albicans and C. glabrata were much higher than those determined against $C$. cladosporioides. Derivatives 1-8 presented the same pattern of activity against the two Candida species.

From twelve hydrazones tested, only five showed some antifungal activity. Compounds 10, 19 and $\mathbf{2 0}$ proved to be active against $C$. glabrata, suggesting some selectivity. Compound $\mathbf{1 0}$ was very active, with $\mathrm{MIC}_{50}<1.20 \mu \mathrm{M}$. 11 and 12 were active against $C$. glabrata and $C$. cladosporioides. Both were more active than nystatin against $C$. cladosporioides. Compounds $\mathbf{1 2}$ and $\mathbf{2 0}$ proved to be more active than nystatin against $C$. glabrata. 12, which bears a $p \mathrm{NO}_{2} \mathrm{Ph}$ substituent, showed higher activity against $C$. glabrata $\left(\mathrm{MIC}_{50}<0.9 \mu \mathrm{M}\right)$ and $C$. cladosporioides $\left(\mathrm{MIC}_{50}=1.6 \mu \mathrm{M}\right)$ than nystatin $\left(\mathrm{MIC}_{50}=1.05 \mu \mathrm{M}\right.$ and $>269 \mu \mathrm{M}$, respectively).

Since compounds 1 and $\mathbf{3}$ have in common the presence of a primary amine group at N5 we can presume that steric hindrance at this position in the other thiosemicarbazones could lead to weaker interaction with the biological target, with decreasing of activity.

None of the tested thiosemicarbazones presented a significant activity against $A$. flavus. This is an important finding, since selectivity is a very welcome property of a given antifungal, allowing an optimum exploitation of its capacity without affecting beneficiating microorganisms present in a given crop.

Evaluation of activity for the imidazole-carboxaldehyde-derived hydrazones 9-12 reveals that the presence of the phenyl group in 10-12 significantly improves antifungal activity in relation to the presence of the methyl group in 9. Among the imidazole-acetophenone-derived hydrazones the presence of the $p$ - $\mathrm{ClPh}$ or $p-\mathrm{NO}_{2} \mathrm{Ph}$ groups seems to favor antifungal activity against $C$. glabrata in compounds 19 and 20.The presence of the $p-\mathrm{NO}_{2} \mathrm{Ph}$ group in 12 and 20 and of the $p$-ClPh group in 11 and 19 seems to be very effective to increase the antifungal effect of the compounds. 
Table 3. $\mathrm{MIC}_{50}$ of imidazole-derived thiosemicarbazones and hydrazones against phytopathogenic and human pathogenic fungi.

\begin{tabular}{|c|c|c|c|c|}
\hline \multirow{2}{*}{ Compounds } & \multicolumn{4}{|c|}{$\mathrm{MIC}_{50}(\mu \mathrm{M})$} \\
\hline & C. glabrata & C. albicans & A. flavus & C. cladosporioides \\
\hline $\operatorname{ImT}(\mathbf{1})$ & $>1477.45$ & $>1477.45$ & $>1477.45$ & 5.79 \\
\hline $\operatorname{ImTPh}(\mathbf{2})$ & $>1019.16$ & $>1019.16$ & $>1019.16$ & 1019.16 \\
\hline 4ImBzT (3) & 509.58 & $>509.58$ & $>1019.16$ & 2.00 \\
\hline 4ImBzTM (4) & $>964.02$ & $>964.02$ & $>964.02$ & $>964.02$ \\
\hline 4ImBzTPh (5) & $>777.99$ & $>777.99$ & $>777.99$ & $>777.99$ \\
\hline $4 \operatorname{ImAcT}(\mathbf{6})$ & $>964.02$ & $>964.02$ & $>964.02$ & $>964.02$ \\
\hline 4ImAcTM (7) & $>914.54$ & $>914.54$ & $>914.54$ & $>914.54$ \\
\hline $4 \operatorname{ImAcTPh}(\mathbf{8})$ & $>745.33$ & $>745.33$ & $>745.33$ & $>745.33$ \\
\hline 4(5)ImMe (9) & $>1643$ & $>1643$ & 1643 & $>1643$ \\
\hline 4(5)ImPh (10) & $<1.20$ & $>1167$ & $>1167$ & 1167 \\
\hline 4(5)ImpClPh (11) & 15.70 & 1005.20 & $>1005.20$ & 7.80 \\
\hline 4(5)Im $p \mathrm{NO}_{2} \mathrm{Ph}(12)$ & $<0.90$ & $>964.40$ & 482.20 & 1.90 \\
\hline 4ImBzMe (13) & $>1095.20$ & $>1095.20$ & $>1095.20$ & $>1095.20$ \\
\hline 4ImBzPh (14) & $>861.10$ & $>861.10$ & $>861.10$ & $>861.10$ \\
\hline 4ImBzpClPh (15) & 769.80 & $>769.80$ & $>769.80$ & $>769.80$ \\
\hline $4 \operatorname{ImBz} p \mathrm{NO}_{2} \mathrm{Ph}(\mathbf{1 6})$ & $>745.60$ & $>745.60$ & $>745.60$ & $>745.60$ \\
\hline 4ImAcMe (17) & $>1031.90$ & $>1031.90$ & $>1031.90$ & $>1031.90$ \\
\hline 4ImAcPh (18) & $>821.40$ & $>821.40$ & $>821.40$ & $>821.40$ \\
\hline $4 \operatorname{ImAc} p \operatorname{ClPh}(\mathbf{1 9})$ & 1.40 & $>737.90$ & $>737.90$ & $>737.90$ \\
\hline $4 \operatorname{ImAc} p \mathrm{NO}_{2} \mathrm{Ph}(\mathbf{2 0})$ & $<0.68$ & $>715.60$ & $>715.60$ & $>715.60$ \\
\hline Nystatin & 1.05 & $>269$ & $>269$ & $>269$ \\
\hline
\end{tabular}

\section{Experimental}

\subsection{General}

All common chemicals were purchased from Aldrich and used without further purification. Thiosemicarbazones and hydrazones were prepared according to procedures previously employed by our group [15,19,31-33]. Melting points were determined using the digital Mettler Toledo FP90 equipment. Partial elemental analyses were performed on a Perkin Elmer CHN 2400 analyzer. Infrared spectra were recorded on a Perkin Elmer FT-IR Spectrum GX spectrometer using KBr plates (4000-400 $\left.\mathrm{cm}^{-1}\right)$. NMR spectra were obtained with a Bruker DPX-200 Avance (200 MHz) spectrometer using DMSO- $d_{6}$ as the solvent and TMS as internal reference. X-ray diffraction data collection was performed on an Oxford-Diffraction GEMINI diffractometer (LabCri-UFMG) using graphite-Enhance Source Mo K $\alpha$ radiation $(\lambda=0.71069 \AA$ or $\mathrm{Cu} \mathrm{K} \alpha$ radiation $(\lambda=1.54180 \AA$ Data integration and scaling of the reflections were performed with the Crysalis suite [34]. Final unit cell parameters were based on the fitting of all reflections positions. 


\subsection{Synthesis of Thiosemicarbazone Derivatives (1-8)}

The imidazole-derived thiosemicarbazones were prepared by reacting equimolar amounts ( $2 \mathrm{mmol})$ of 4(5)-imidazole-carboxaldehyde, 4-(1H-imidazole-1-yl)-benzaldehyde or 4-(1H-imidazole-1-yl)acetophenone with the suitable thiosemicarbazide using methanol as solvent. The reaction mixture was kept under reflux for $6 \mathrm{~h}$. After cooling to room temperature the resulting solids were filtered off, washed with ethanol and ether and dried in vacuum.

4(5)-Imidazole-carboxaldehyde-thiosemicarbazone (ImT) (1): Yield: 89\%. White solid. M.p.: 201-202 ${ }^{\circ} \mathrm{C}$. Anal. Calc. for $\mathrm{C}_{5} \mathrm{H}_{7} \mathrm{~N}_{5} \mathrm{~S}$ : C, 35.49; H, 4.17; N, 41.39. Found: C, 35.20; H, 4.04; N, 40.83\%. FW: $169.21 \mathrm{~g} \mathrm{~mol}^{-1}$. IR $\left(\mathrm{KBr}, \mathrm{cm}^{-1}\right): v(\mathrm{NH}) 3446 \mathrm{~s}, v(\mathrm{C}=\mathrm{N}) 1616 \mathrm{~s}, v(\mathrm{C}=\mathrm{S}) 848 \mathrm{~m} .{ }^{1} \mathrm{H}-\mathrm{NMR}$ (DMSO- $d_{6}, \delta$, $E, Z$ configuration): $13.21(\mathrm{~s}, 1 \mathrm{H}, \mathrm{N} 4 \mathrm{H}, Z), 12.89(\mathrm{~s}, 1 \mathrm{H}, \mathrm{N} 1 \mathrm{H}, E, Z), 11.43(\mathrm{~s}, 1 \mathrm{H}, \mathrm{N} 4 \mathrm{H}, E), 8.28$ $\left(\mathrm{s}, 1 \mathrm{H}, \mathrm{N}^{2} \mathrm{H}_{\mathrm{a}}, Z\right), 8.21\left(\mathrm{~s}, 1 \mathrm{H}, \mathrm{N} 5 \mathrm{H}_{\mathrm{b}}, Z\right), 8.08(\mathrm{~s}, 1 \mathrm{H}, \mathrm{H} 4, E), 8.01$ (s, 1H, H2, Z), $7.91\left(\mathrm{~s}, 1 \mathrm{H}, \mathrm{N}^{2} \mathrm{H}_{\mathrm{a}}, E\right)$, $7.91\left(\mathrm{~s}, 1 \mathrm{H}, \mathrm{N}_{\mathrm{H}}, E\right), 7.73$ (s, $\left.1 \mathrm{H}, \mathrm{H} 1, E\right), 7.47$ (s, $\left.1 \mathrm{H}, \mathrm{H} 1, Z\right), 7.28(\mathrm{~s}, 1 \mathrm{H}, \mathrm{H} 2, E) .{ }^{13} \mathrm{C}-\mathrm{NMR}$ (DMSO- $d_{6}$, $\delta, E, Z$ configuration): $177.80(\mathrm{C} 5, E), 177.58(\mathrm{C} 5, Z), 138.18$ (C4, Z), $135.54(\mathrm{C} 3, E, Z), 135.47$ (C4, E), $134.76(\mathrm{C} 2, Z), 131.14(\mathrm{C} 2, E), 121.56(\mathrm{C} 1, E), 121.57(\mathrm{C} 1, Z)$.

4(5)-Imidazole-carbaldehyde-N(5)-phenylthiosemicarbazone (ImTPh) (2): Yield: 80\%. White solid. Mp.: 219-220 ${ }^{\circ} \mathrm{C}$. Anal. Calc. for $\mathrm{C}_{11} \mathrm{H}_{11} \mathrm{~N}_{5} \mathrm{~S}$ : C, 53.86; H, 4.52; N, 28.55. Found: C, 53.93; H, 4.52; $\mathrm{N}, 28.52 \%$. FW: $245.30 \mathrm{~g} \mathrm{~mol}^{-1}$. IR $\left(\mathrm{KBr}, \mathrm{cm}^{-1}\right): \mathrm{v}(\mathrm{NH}) 3358 \mathrm{~s}, \mathrm{v}(\mathrm{C}=\mathrm{N}) 1635 \mathrm{~s}, \mathrm{v}(\mathrm{C}=\mathrm{S}) 841 \mathrm{~m} .{ }^{1} \mathrm{H}-\mathrm{NMR}$ $\left[\mathrm{DMSO}-d_{6}, \delta, J(\mathrm{~Hz}), E, Z\right.$ configuration, thiol]: $13.41(\mathrm{~s}, 1 \mathrm{H}, \mathrm{N} 4 \mathrm{H}, Z) ; 12.89$ (s, $1 \mathrm{H}, \mathrm{N} 1 \mathrm{H}, E, Z$, thiol); 11.78 (s, 1H, N4H, E); 10.18 (s, 1H, N5H b E); 10.06 (s, 1H, N5H,$Z$ ); 8.79 (s, 1H, H4, thiol); 8.07 (s, 1H, H4, Z); 7.89 (s, 1H, H2, Z); 7.87 (s, 1H, H1, thiol); 7.87 (s, 1H, H2, thiol); 7.87 (s, 1H, H4, E); 7.86 (t, 2H, H7, H11, 8.56, E,Z); 7.75 (s, 1H, H1, E, Z); 7.35 (s, 1H, H2, E); 7.61 (t, 2H, H8, H10, 8.55, E, $Z$, thiol); 7.17 (t, $1 \mathrm{H}, \mathrm{H} 9,7.89, \mathrm{E}, Z$, thiol). ${ }^{13} \mathrm{C}-\mathrm{NMR}$ (DMSO- $d_{6}, \delta, E, Z$ configuration, thiol): 175.47 (C5, Z); 175.29 (C5, E); 172.05 (C5, thiol); 165.20 (C6, thiol); 138.99 (C6, E, Z); 138.84 (C1, thiol); 137.57 (C4, E); 136.68 (C4, Z); 135.74 (C4, thiol); 134.70 (C2, Z); 135.36 (C3, E, Z, thiol); 131.28 (C2, E); 128.70 (C7, C11, thiol); 128.61 (C2, thiol ); 127.99 (C7, C11, E, Z); 125.15 (C8, C10, thiol); 124.96 (C8, C10, E, Z); 124.73 (C9, E, Z); 121.96 (C1, E, Z); 118.80 (C9, thiol).

4-(1H-Imidazole-1-yl)-benzaldehyde-thiosemicarbazone (4ImBzT) (3): Yield: 96\%. White solid. M.p.: 244-245 ${ }^{\circ} \mathrm{C}$. Anal. Calc. for $\mathrm{C}_{11} \mathrm{H}_{11} \mathrm{~N}_{5} \mathrm{~S}$ : C, 53.86; H, 4.52; N, 28.55. Found: C, 53.68; H, 4.19; N, 28.75\%. FW: $245.30 \mathrm{~g} \mathrm{~mol}^{-1}$. IR $\left(\mathrm{KBr}, \mathrm{cm}^{-1}\right): \mathrm{v}(\mathrm{NH}) 3444 \mathrm{~s}, \mathrm{v}(\mathrm{C}=\mathrm{N}) 1616 \mathrm{~s}, \mathrm{v}(\mathrm{C}=\mathrm{S}) 848 \mathrm{~m} .{ }^{1} \mathrm{H}-\mathrm{NMR}$ [DMSO- $\left.d_{6}, \delta, J(\mathrm{~Hz})\right]: 11.53(\mathrm{~s}, 1 \mathrm{H}, \mathrm{N} 4 \mathrm{H}) ; 8.38(\mathrm{~s}, 1 \mathrm{H}, \mathrm{H} 10) ; 8.28\left(\mathrm{~s}, 1 \mathrm{H}, \mathrm{N}^{2} \mathrm{H}_{\mathrm{a}}\right) ; 8.14\left(\mathrm{~s}, 1 \mathrm{H}, \mathrm{N}^{2} \mathrm{H}_{\mathrm{b}}\right)$; 8.02 (s, 1H, H1); 7.98 (d, 2H, H5, H9, 8.30); 7.85 (s, 1H, H3); 7.72 (d, 2H, H6, H8, 8.31); 7.16 (s, 1H, H2).

${ }^{13} \mathrm{C}-\mathrm{NMR}$ (DMSO- $\left.d_{6}, \delta\right): 177.96$ (C11); 141.25 (C1); 137.56 (C4); 135.49 (C10); 132.62 (C7); 129.99 (C2); 128.74 (C6); 128.74 (C8); 120.11 (C5); 120.11 (C9); 117.79 (C3).

4-(1H-Imidazole-1-yl)-benzaldehyde-N(5)-methylthiosemicarbazone (4ImBzTM) (4): Yield: 76\%. White solid. M.p.: 204-206 ${ }^{\circ} \mathrm{C}$. Anal. Calc. for $\mathrm{C}_{12} \mathrm{H}_{13} \mathrm{~N}_{5} \mathrm{~S}$ : C, 55.58; H, 5.05; N, 27.01. Found: C, 55.88; H, 4.43; N, 26.95\%. FW: $259.33 \mathrm{~g} \mathrm{~mol}^{-1}$. IR $\left(\mathrm{KBr}, \mathrm{cm}^{-1}\right): v(\mathrm{NH}) 3145 \mathrm{~s}, v(\mathrm{C}=\mathrm{N}) 1610 \mathrm{~s}, v(\mathrm{C}=\mathrm{S})$ 835m. ${ }^{1} \mathrm{H}-\mathrm{NMR}\left[\mathrm{DMSO}-d_{6}, \delta, J(\mathrm{~Hz})\right]: 11.57(\mathrm{~s}, 1 \mathrm{H}, \mathrm{N} 4 \mathrm{H}) ; 8.60\left(\mathrm{~s}, 1 \mathrm{H}, \mathrm{N} 5 \mathrm{H}_{\mathrm{a}}\right) ; 8.36(\mathrm{~s}, 1 \mathrm{H}, \mathrm{H} 10) ; 8.07$ (s, 1H, H1); 7.93 (d, 2H, H5, H9, 7.52); 7.82 (s, 1H, H3); 7.72 (d, 2H, H6, H8, 8.53); 7.13 (s, 1H, H2); 
3.03 (d, 3H, H12, 4.37). ${ }^{13} \mathrm{C}-\mathrm{NMR}$ (DMSO-d,$\left.\delta\right): 177.67$ (C11); 140.49 (C1); 137.49 (C4); 135.49 (C10); 132.69 (C7); 129.99 (C2); 128.58 (C6); 128.58 (C8); 120.10 (C5); 120.10 (C9); 117.78 (C3); 30.81 (C12).

4-(1H-Imidazole-1-yl)-benzaldehyde-N(5)-phenylthiosemicarbazone (4ImBzTPh) (5): Yield: 83\%. White solid. M.p.: $194-196{ }^{\circ} \mathrm{C}$. Anal. Calc. for $\mathrm{C}_{17} \mathrm{H}_{15} \mathrm{~N}_{5} \mathrm{~S}$ : C, 63.53; H, 4.70; N, 21.79. Found: C, 63.03; H, 4.70; N, 21.82\%. FW: $321.34 \mathrm{~g} \mathrm{~mol}^{-1}$. IR $\left(\mathrm{KBr}, \mathrm{cm}^{-1}\right): \mathrm{v}(\mathrm{NH}) 3358 \mathrm{~s}, \mathrm{v}(\mathrm{C}=\mathrm{N}) 1635 \mathrm{~s}$, $v(\mathrm{C}=\mathrm{S}) 837 \mathrm{~m} .{ }^{1} \mathrm{H}-\mathrm{NMR}$ [DMSO- $\left.d_{6}, \delta, J(\mathrm{~Hz})\right]: 8.38(\mathrm{~s}, 1 \mathrm{H}, \mathrm{H} 10) ; 8.20(\mathrm{~s}, 1 \mathrm{H}, \mathrm{H} 1) ; 8.06(\mathrm{~d}, 2 \mathrm{H}, \mathrm{H} 6$, $\mathrm{H} 8,8.41) ; 7.84$ (s, 1H, H3); 7.70 (d, 2H, H5, H9, 8.42); 7.58 (d, 2H, H13, H17, 7.67); 7.57 (t, 1H, $\mathrm{H} 16) ; 7.38$ (t, 2H, H14, H16, 7.57); 7.14 (s, 1H, H2). ${ }^{13} \mathrm{C}$ NMR (DMSO- $d_{6}, \delta$ ): 176.01 (C11); 141.68 (C1), 139.00 (C12); 137.69 (C4); 135.49 (C10); 132.40 (C7); 130.01 (C2), 129.05 (C8); 129.05 (C6); 127.99 (C14, C16); 125.97 (C13, C17); 125.34 (C15); 120.04 (C5); 120.03 (C9); 117.75 (C3).

4-(1H-Imidazole-1-yl)-acetophenone-N(5)-phenylthiosemicarbazone (4ImAcT) (6): Yield: 83\%. White solid. M.p.: 249-251 ${ }^{\circ} \mathrm{C}$. Anal. Calc. for $\mathrm{C}_{12} \mathrm{H}_{13} \mathrm{~N}_{5} \mathrm{~S}: \mathrm{C}, 55.58 ; \mathrm{H}, 5.05 ; \mathrm{N}, 27.01$. Found: C, 55.31; H, 4.98; N, 27.43\%. FW: $295.33 \mathrm{~g} \mathrm{~mol}^{-1}$. IR $\left(\mathrm{KBr}, \mathrm{cm}^{-1}\right)$ : v(NH) 3444s, v(C=N) 1616s, v(C=S) 848m. ${ }^{1} \mathrm{H}-\mathrm{NMR}\left[\mathrm{DMSO}-d_{6}, \delta, J(\mathrm{~Hz})\right]: 10.27(\mathrm{~s}, 1 \mathrm{H}, \mathrm{N} 4 \mathrm{H}) ; 8.35$ (s, 1H, H1); 8.33 (s, 2H, N5H); 8.08 (d, 2H, H6, H8, 8.67); 7.82 (s, 1H, H3); 7.66 (d, 2H, H5, H9, 8.66); 7.12 (s, 1H, H2); 2.32(s, 3H, H12). ${ }^{13} \mathrm{CNMR}\left(\mathrm{DMSO}-d_{6}, \delta\right): 178.83$ (C11); 145.85 (C4); 137.25 (C7); 135.93 (C10); 135.52 (C1); 130.00 (C2); 128.15 (C6); 128.15 (C8); 119.63 (C5); 119.63 (C9); 117.85 (C3); 13.91 (C12).

4-(1H-Imidazole-1-yl)-acetophenone-N(5)-methylthiosemicarbazone (4ImAcTM) (7): Yield: 76\%. White solid. M.p.: $215-216{ }^{\circ}$ C. Anal. Calc. for $\mathrm{C}_{13} \mathrm{H}_{15} \mathrm{~N}_{5} \mathrm{~S}$ : C, 57.12; H, 5.53; N, 25.62. Found: C, 57.17; H, 5.57; N, 25.55\%. FW: $273.36 \mathrm{~g} \mathrm{~mol}^{-1}$. IR $\left(\mathrm{KBr}, \mathrm{cm}^{-1}\right): v(\mathrm{NH}) 3358 \mathrm{~s}, \mathrm{v}(\mathrm{C}=\mathrm{N}) 1615 \mathrm{~s}, \mathrm{v}(\mathrm{C}=\mathrm{S})$ 830m. ${ }^{1} \mathrm{H}-\mathrm{NMR}\left[\mathrm{DMSO}-d_{6}, \delta, J(\mathrm{~Hz})\right]: 10.28(\mathrm{~s}, 1 \mathrm{H}, \mathrm{N} 4 \mathrm{H}) ; 8.54\left(\mathrm{~s}, 1 \mathrm{H}, \mathrm{N} 5 \mathrm{H}_{\mathrm{a}}\right) ; 8.37(\mathrm{~s}, 1 \mathrm{H}, \mathrm{H} 1) ; 8.08$ (d, 2H, H6, H8, 8.70); 7.83 (s, 1H, H3); 7.67 (d, 2H, H5, H9, 8.72); 7.13 (s, 1H, H2); 3.05 (d, 3H, H13); 2.32 (s, 3H, H12). ${ }^{13} \mathrm{C}-\mathrm{NMR}\left(\mathrm{DMSO}_{-}, \delta\right): 175.56$ (C11); 146.50 (C4); 137.18 (C7); 135.96 (C10); 135.50 (C1); 129.97 (C2); 128.06 (C8); 128.06 (C6); 119.62 (C9); 119.62 (C5); 117.82 (C3); 13.91 (C12); 31.10 (C13).

4-(1H-Imidazole-1-yl)-acetophenone-N(5)-phenylthiosemicarbazone (4ImAcTPh) (8): Yield: 70\%. White solid. M.p.: 191-192 ${ }^{\circ} \mathrm{C}$. Anal. Calc. for $\mathrm{C}_{18} \mathrm{H}_{17} \mathrm{~N}_{5} \mathrm{~S}$ : C, 64.45; H, 5.11; N, 20.88. Found: C, 64.39, H, 5.98; N, 20.60\%. FW: $335.42 \mathrm{~g} \mathrm{~mol}^{-1}$. IR $\left(\mathrm{KBr}, \mathrm{cm}^{-1}\right): \mathrm{v}(\mathrm{NH}) 3286 \mathrm{~s}, \mathrm{v}(\mathrm{C}=\mathrm{N}) 1612 \mathrm{~s}, \mathrm{v}(\mathrm{C}=\mathrm{S})$ 832m. ${ }^{1} \mathrm{H}-\mathrm{NMR}$ [DMSO- $d_{6}, \delta, J(\mathrm{~Hz})$ ]: $8.39(\mathrm{~s}, 1 \mathrm{H}, \mathrm{H} 1) ; 8.18$ (d, 2H, H6, H8, 8.57); 7.85 (s, 1H, H3); 7.70 (d, 2H, H5, H9, 8.60); 7.58 (d, 2H, H14, H18, 7.80); 7.39 (t, 2H, H15, H17, 7.66); 7.23 (t, 1H, H16, 7.38); 7.16 (s, 1H, H2); 2.42 (s, 3H, H12). ${ }^{13} \mathrm{C}-\mathrm{NMR}$ (DMSO-d,$\delta$ ): 176.99 (C11); 147.89 (C4); 139.13 (C13); 137.35 (C7); 135.78 (C10); 135.52 (C1), 129.89 (C2), 128.40 (C6, C8); 128.06 (C15, C17); 125.97 (C14, C18), 125.39 (C16); 119.64 (C5, C9); 117.84 (C3); 14.33 (C12).

\subsection{Synthesis of Hydrazone Derivatives (9-20)}

The imidazole-derived hydrazones were prepared by mixing equimolar amounts (2 mmol) of 4(5)-imidazole-carboxaldehyde, 4-(1H-imidazole-1-yl)-benzaldehyde and 4-(1H-imidazole-1-yl)- 
acetophenone with the desired hydrazide in methanol with addition of three drops of acetic acid as catalyst. The reaction mixture was kept under reflux for $6 \mathrm{~h}$. After cooling to room temperature the resulting solids were filtered off, washed with ethanol and ether and dried in vacuum. In the case of compound 9, the synthesis was carried out using acetonitrile as solvent.

4(5)-Imidazole-carboxaldehyde-acetylhydrazone [4(5)ImM] (9): Yield: 76\%. White solid. M.p.: 163-164 ${ }^{\circ} \mathrm{C}$. Anal. Calc. for $\mathrm{C}_{6} \mathrm{H}_{8} \mathrm{~N}_{4} \mathrm{O}: \mathrm{C}, 47.63 ; \mathrm{H}, 5.30 ; \mathrm{N}, 36.82$. Found $\mathrm{C}, 47.45 ; \mathrm{H}, 5.52 ; \mathrm{N}$, $36.86 \%$. FW: $152.15 \mathrm{~g} \mathrm{~mol}^{-1}$. IR $\left(\mathrm{KBr}, \mathrm{cm}^{-1}\right): \mathrm{v}(\mathrm{N}-\mathrm{H}) 3210 \mathrm{~s} ; \mathrm{v}(\mathrm{N}-\mathrm{H})_{\text {imidazole }} 3097-3004 \mathrm{~m} ; \mathrm{v}\left(\mathrm{CH}_{3 \text { ass }}\right)$ $2930 \mathrm{~m} ; \mathrm{v}\left(\mathrm{CH}_{3 \mathrm{~s}}\right) 2864 \mathrm{~m} ; \mathrm{v}(\mathrm{C}=\mathrm{O}) 1675 \mathrm{~s} ; \mathrm{v}(\mathrm{C}=\mathrm{N}) 1615 \mathrm{~m} .{ }^{1} \mathrm{H}-\mathrm{NMR}$ (DMSO-d $, \delta, E, Z$ configuration, enol): $13.30(\mathrm{~s}, 1 \mathrm{H}, \mathrm{N} 4 \mathrm{H}, Z) ; 12.93$ (s, 1H, N4H, E); 12.93 (s, 1H, OH, enol); 11.22 (s, 1H, N1H, enol); 11.03 (s, 1H, N1H, E); 9.76 (s, 1H, N1H, Z); 8.10 (s, 1H, H4, enol); 8.03 (s, 1H, H4, Z), 7.94 (s, 1H, H4, E); 7.76 (s, 1H, H1, Z); 7.68 (s, 1H, H1, E); 7.43 (s, 1H, H1, enol); 7.37 (s, 1H, H2, Z); 7.24 (s, 1H, H2, E, enol); 2.02 (s, 3H, H6, Z), 2.16 (s, 3H, H6, E), 1.94 (s, 3H, H6, enol). ${ }^{13} \mathrm{C}-\mathrm{NMR}$ (DMSO-d $d_{6} \delta, E, Z$ configuration, enol): 171.89 (C5, E); 171.57 (C5, Z); 168.35 (C5, enol); 139.55 (C4, Enol); 137,0 (C4, E); 136.33 (C4, Z); 137.80 (C2, enol); 134.13 (C2, Z); 131.80 (C2, E); 137.36 (C3, Z); 121.25 (C3, enol); 120.19 (C3, E); 135.74 (C1, E); 135.53 (C1, enol); 22.15 (C6, Z); 21.54 (C6, enol); 20.08 (C6, E).

4(5)-Imidazole-carboxaldehyde-benzoylhydrazone [4(5)ImPh] (10): Yield: 81\%. White solid. M.p.: 276-278 ${ }^{\circ} \mathrm{C}$. Anal. Calc. for $\mathrm{C}_{11} \mathrm{H}_{10} \mathrm{~N}_{4} \mathrm{O}: \mathrm{C}, 61.67 ; \mathrm{H}, 4.71 ; \mathrm{N}, 26.15$. Found: C, 61.80; H, 4.68; N, 26.06\%. FW: $214.22 \mathrm{~g} \mathrm{~mol}^{-1}$. IR $\left(\mathrm{KBr}, \mathrm{cm}^{-1}\right): v(\mathrm{~N}-\mathrm{H}) 3213 \mathrm{~s} ; \mathrm{v}(\mathrm{N}-\mathrm{H})_{\text {imidazole }}$ 3100-3027 m; $\mathrm{v}(\mathrm{C}=\mathrm{O})$ $1644 \mathrm{~s} ; \mathrm{v}(\mathrm{C}=\mathrm{N}) 1626 \mathrm{~m} .{ }^{1} \mathrm{H}-\mathrm{NMR}\left[\mathrm{DMSO}-d_{6}, \delta, J(\mathrm{~Hz})\right]: 14.29(\mathrm{~s}, 1 \mathrm{H}, \mathrm{N} 4 \mathrm{H}) ; 8.37(\mathrm{~s}, 1 \mathrm{H}, \mathrm{N} 1 \mathrm{H}) ; 8.11$ (s, 1H, H4); 7.89 (d, 2H, H7, H11, 6.86); 7.75 (s, 1H, H1); 7.58 (m, 1H, H9); 7.53 (m, 2H, H8, H10, 6.91); 7.51(s, 1H, H2). ${ }^{13} \mathrm{C}-\mathrm{NMR}$ (DMSO-d $\left.d_{6}, \delta\right): 162.81$ (C5); 136.61 (C4); 135.67 (C2); 135.03 (C1); 133.55 (C6); 131.54 (C9); 128.14 (C8, C10); 127.44 (C7, C11); 121.26 (C3).

4(5)-Imidazole-carboxaldehyde-para-chloro-benzoylhydrazone [4(5)ImpClPh] (11): Yield: 56\%. White solid. M.p.: $277-280{ }^{\circ} \mathrm{C}$. Anal. Calc. for $\mathrm{C}_{11} \mathrm{H}_{9} \mathrm{ClN}_{4} \mathrm{O}: \mathrm{C}, 53.13 ; \mathrm{H}, 3.65 ; \mathrm{N}, 22.53$. Found C, 53.08; $\mathrm{H}, 3.59$; N, 22.32\%. FW: $248.67 \mathrm{~g} \mathrm{~mol}^{-1}$. IR (KBr, $\left.\mathrm{cm}^{-1}\right): \mathrm{v}(\mathrm{N}-\mathrm{H}) 3200 \mathrm{~s} ; \mathrm{v}(\mathrm{N}-\mathrm{H})_{\text {imidazole }}$ 3100-3058 m; $v(\mathrm{C}=\mathrm{O}) 1660 \mathrm{~s} ; \mathrm{v}(\mathrm{C}=\mathrm{N}) 1615 \mathrm{~m} .{ }^{1} \mathrm{H}-\mathrm{NMR}$ [DMSO-d $\left., \delta, J(\mathrm{~Hz})\right]: 14.34(\mathrm{~s}, 1 \mathrm{H}, \mathrm{N} 4 \mathrm{H}) ; 8.39(\mathrm{~s}, 1 \mathrm{H}$, $\mathrm{N} 1 \mathrm{H}) ; 8.12$ (s, 1H, H4); 7.95 (d, 2H, H7, H11, 8.55); 7.79 (s, 1H, H1); 7.65(d, 2H, H8, H10, 8.64); 7.55(s, 1H, H2). ${ }^{13} \mathrm{C}-\mathrm{NMR}\left(\mathrm{DMSO}-d_{6}, \delta\right): 161.26$ (C5); 136.50 (C4); 136.61 (C9); 135.99 (C2); 135.59 (C1); 132.23 (C6); 128.99 (C8, C10); 128.81 (C7, C11); 121.61 (C3).

4(5)-Imidazole-carboxaldehyde-para-nitro-benzoylhydrazone [4(5) $\mathrm{ImpNO}_{2} \mathrm{Ph}$ ] (12): Yield: 76\%. Yellow solid. M.p.: $>300{ }^{\circ} \mathrm{C}$. Anal. Calc. for $\mathrm{C}_{11} \mathrm{H}_{9} \mathrm{~N}_{5} \mathrm{O}_{3}: \mathrm{C}, 50.97 ; \mathrm{H}, 3.50 ; \mathrm{N}, 27.02$. Found: C, 50.58; H, 3.43; N, 26.96\%; mol wt, $259.22 \mathrm{~g} \mathrm{~mol}^{-1}$. IR (KBr, $\left.\mathrm{cm}^{-1}\right): \mathrm{v}(\mathrm{N}-\mathrm{H}) 3159 \mathrm{~s}$; v(N-H) imidazole 3127-3063 m; v(C=O) $1687 \mathrm{~s} ; \mathrm{v}(\mathrm{C}=\mathrm{N}) 1619 \mathrm{~m} .{ }^{1} \mathrm{H}-\mathrm{NMR}$ [DMSO-d $\left., \delta, J(\mathrm{~Hz})\right]: 14.54(\mathrm{~s}, 1 \mathrm{H}, \mathrm{N} 4 \mathrm{H})$; 8.41 (d, 2H, H8, H10, 6.89); 8.37 (s, 1H, N1H); 8.18 (m, 2H, H7, H11); 8.13 (m, 1H, H4); 7.82 $(\mathrm{s}, 1 \mathrm{H}, \mathrm{H} 1) ; 7.61(\mathrm{~s}, 1 \mathrm{H}, \mathrm{H} 2)$. Due the low solubility of compound $\mathbf{1 2}$ was impossible to record the ${ }^{13} \mathrm{C}-\mathrm{NMR}$ spectrum. 
4-(1H-Imidazole-1-yl)-benzaldehyde-acetylhydrazone (4ImBzM) (13): Yield: 65\%. White solid. M.p.: 148-150 ${ }^{\circ} \mathrm{C}$. Anal. Calc. for $\mathrm{C}_{12} \mathrm{H}_{12} \mathrm{~N}_{4} \mathrm{O}$ : C, 63.14; H, 5.30; N, 24.55. Found $\mathrm{C}, 63.07 ; \mathrm{H}, 5.23 ; \mathrm{N}$, 24.66\%. FW: $228.25 \mathrm{~g} \mathrm{~mol}^{-1}$. IR $\left(\mathrm{KBr}, \mathrm{cm}^{-1}\right): \mathrm{v}(\mathrm{N}-\mathrm{H}) 3171 \mathrm{~s} ; \mathrm{v}\left(\mathrm{CH}_{3 \mathrm{ass}}\right) 2978 \mathrm{~m} ; \mathrm{v}\left(\mathrm{CH}_{3 \mathrm{~s}}\right) 2863 \mathrm{~m}$; $v(\mathrm{C}=\mathrm{O}) 1659 \mathrm{~s} ; \mathrm{v}(\mathrm{C}=\mathrm{N}) 1618 \mathrm{~m} .{ }^{1} \mathrm{H}$ NMR [DMSO- $d_{6}, \delta, J(\mathrm{~Hz})$, keto, enol tautomers]: $11.49(\mathrm{~s}, 1 \mathrm{H}$, $\mathrm{N} 4 \mathrm{H}$, keto); 11.35 (s, 1H, OH, enol); 8.36 (s, 1H, H1, keto); 8.20 (s, 1H, H10, keto); 8.03 (s, 1H, H10, enol); 7.83 (s, 1H, H3, keto); 7.81 (m, 2H, H6, H8, keto); 7.76 (m, 2H, H5, H9, keto); 7.15 (s, 1H, H2, keto); 2.23 (s, 3H, H12, enol); 1.99 (s, 3H, H12, keto). ${ }^{13} \mathrm{C}-\mathrm{NMR}$ (DMSO-d,$\delta$, keto, enol tautomers): 172.00 (C11, keto); 165.67 (C11, enol); 144.49 (C10, keto); 141.38 (C10, enol); 137.63 (C4, keto); 135.45 (C1, keto); 132.70 (C7, keto); 130.02 (C2, keto); 127.97 (C6, C8, keto); 120.30 (C5, C9, keto); 117.75 (C3, keto); 21.58 (C12, keto), 20.12 (C12, enol).

4-(1H-Imidazole-1-yl)-benzaldehyde-benzoylhydrazone (4ImBzPh) (14): Yield: 84\%. White solid. M.p.: 250-252 ${ }^{\circ} \mathrm{C}$. Anal. Calc. for $\mathrm{C}_{17} \mathrm{H}_{14} \mathrm{~N}_{4} \mathrm{O}$ : C, 70.33; H, 4.86; N, 19.30. Found: C, 70.10; H, 4.70; $\mathrm{N}, 19.47 \%$. FW: $290.32 \mathrm{~g} \mathrm{~mol}^{-1}$. IR $\left(\mathrm{KBr}, \mathrm{cm}^{-1}\right): v(\mathrm{~N}-\mathrm{H}) 3195 \mathrm{~s} ; \mathrm{v}(\mathrm{C}=\mathrm{O}) 1678 \mathrm{~s} ; \mathrm{v}(\mathrm{C}=\mathrm{N}) 1610 \mathrm{~m}$. ${ }^{1} \mathrm{H}-\mathrm{NMR}$ [DMSO- $\left.d_{6}, \delta, J(\mathrm{~Hz})\right]: 11.95(\mathrm{~s}, 1 \mathrm{H}, \mathrm{N} 4 \mathrm{H}) ; 8.52$ (s, 1H, H10); 8.38 (s,1H, H1); 7.96 (d, 2H, H13, H17, 7.55); 7.90 (m, 2H, H6, H8); 7.86 (s, 1H, H3); 7.80 (m, 2H, H5, H9, 8.46); 7.60 (t, 3H, H14, H15, H16, 7.58); 7.16 (s, 1H, H2). ${ }^{13} \mathrm{C}-\mathrm{NMR}$ (DMSO- $\left.d_{6}, \delta\right): 163.12$ (C11); 146.62 (C10); 137.77 (C4); 135.45 (C1); 133.30 (C12); 132.66 (C7); 131.70 (C15); 130.05 (C2); 128.41 (C6, C8 and C14, C16); 127.58 (C13, C17); 120.27 (C5, C9); 117.72 (C3).

4-(1H-Imidazole-1-yl)-benzaldehyde-para-chloro-benzoylhydrazone (4ImBzpClPh) (15): Yield: 92\%. White solid. M.p.: $244-245{ }^{\circ} \mathrm{C}$. Anal. Calc. for $\mathrm{C}_{17} \mathrm{H}_{13} \mathrm{ClN}_{4} \mathrm{O}: \mathrm{C}, 62.87$; H, 4.03; N, 17.25. Found: C, 62.94; H, 4,01; N, 17.05\%. FW: $324.76 \mathrm{~g} \mathrm{~mol}^{-1}$. IR $\left(\mathrm{KBr}, \mathrm{cm}^{-1}\right): \mathrm{v}(\mathrm{N}-\mathrm{H}) 3189 \mathrm{~s} ; \mathrm{v}(\mathrm{C}=\mathrm{O}) 1678 \mathrm{~s}$; $v(\mathrm{C}=\mathrm{N}) 1608 \mathrm{~m} .{ }^{1} \mathrm{H}-\mathrm{NMR}$ [DMSO- $\left.d_{6}, \delta, J(\mathrm{~Hz})\right]: 12.01(\mathrm{~s}, 1 \mathrm{H}, \mathrm{N} 4 \mathrm{H}) ; 8.51$ (s, 1H, H10); 8.38 (s,1H, H1); 7.97 (d, 2H, H13, H17, 8.27); 7.89 (d, 2H, H6, H8, 8.50); 7.85 (m, 1H, H3); 7.78 (m, 2H, H14, H16, 8.49); 7.64 (d, 2H, H5, H9, 8.29); 7.16 (s, 1H, H2). ${ }^{13} \mathrm{C}-\mathrm{NMR}$ (DMSO- $\left.d_{6}, \delta\right): 162.03$ (C11); 146.96 (C10); 137.84 (C15); 136.55 (C4); 135.45 (C1); 132.54 (C7); 131.97 (C12); 130.05 (C2); 129.49 (C6, C8); 128.49 (C13, C17 and C14, C16); 120.29 (C5, C9); 117.71 (C3).

4-(1H-Imidazole-1-yl)-benzaldehyde-para-nitro-benzoylhydrazine (4ImBzpNO$\left.{ }_{2} P h\right)$ (16): Yield: 96\%. Yellow solid. M.p.: $261-263{ }^{\circ} \mathrm{C}$. Anal. Calc. for $\mathrm{C}_{17} \mathrm{H}_{13} \mathrm{~N}_{5} \mathrm{O}_{3}$ : C, 60.89; H, 3.91; N, 20.89. Found: C, 60.51; H, 3.92; N, 20.78\%. FW: $335.31 \mathrm{~g} \mathrm{~mol}^{-1}$. IR $\left(\mathrm{KBr}, \mathrm{cm}^{-1}\right): \mathrm{v}(\mathrm{N}-\mathrm{H}) 3194 \mathrm{~s} ; \mathrm{v}(\mathrm{C}=\mathrm{O}) 1687 \mathrm{~s}$; $v(\mathrm{C}=\mathrm{N}) 1606 \mathrm{~m} .{ }^{1} \mathrm{H}$ NMR [DMSO- $\left.d_{6}, \delta, J(\mathrm{~Hz})\right]: 12.22(\mathrm{~s}, 1 \mathrm{H}, \mathrm{N} 4 \mathrm{H}) ; 8.52(\mathrm{~s}, 1 \mathrm{H}, \mathrm{H} 10) ; 8.41(\mathrm{~d}, 2 \mathrm{H}$, H14, H16, 7.12); 8.38 (s,1H, H1); 8.18 (d, 2H, H13, H17, 8.49); 7.92 (d, 2H, H6, H8, 8.58); 7.85 (s,

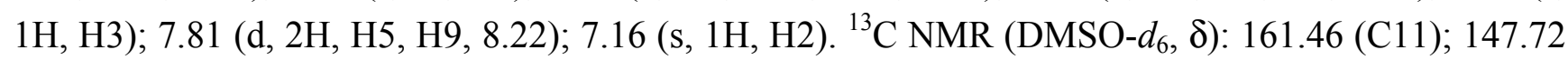
(C10); 149.19 (C15); 138.93 (C4); 137.99 (C12); 135.42 (C1); 132.34 (C7); 130.11 (C2); 129.10 (C13, C17); 128.65 (C6, C8); 123.27 (C14, C16); 120.30 (C5, C9); 117.70 (C3).

4-(Imidazole-1-yl)-acetophenone-acetylhydrazone (4ImAcM) (17): Yield: 68\%. White solid. M.p.: 210-211 ${ }^{\circ} \mathrm{C}$. Anal. Calc. for $\mathrm{C}_{13} \mathrm{H}_{14} \mathrm{~N}_{4} \mathrm{O}$ : C 64.45; H, 5.82; N, 23.13. Found: C, 64.30; H, 5.75; N, 23.24\%. FW: $242.27 \mathrm{~g} \mathrm{~mol}^{-1}$. IR $\left(\mathrm{KBr}, \mathrm{cm}^{-1}\right): \mathrm{v}(\mathrm{N}-\mathrm{H}) 3183 \mathrm{~s} ; \mathrm{v}\left(\mathrm{CH}_{3 \mathrm{ass}}\right) 2933 \mathrm{~m} ; \mathrm{v}\left(\mathrm{CH}_{3 \mathrm{~s}}\right) 2873 \mathrm{~m}$; $v(\mathrm{C}=\mathrm{O}) 1674 \mathrm{~s} ; \mathrm{v}(\mathrm{C}=\mathrm{N}) 1615 \mathrm{~m} .{ }^{1} \mathrm{H}-\mathrm{NMR}$ [DMSO- $d_{6}, \delta, J(\mathrm{~Hz})$, keto, enol tautomers]: $10.51(\mathrm{~s}, 1 \mathrm{H}$, $\mathrm{N} 4 \mathrm{H}$, keto); 10.41 (s, 1H, OH, enol); 8.33 (s, 1H, H1, keto); 7.90 (d, 2H, H6, H8, 8.64, keto); 7.80 
(s, 1H, H3, keto); 7.70 (d, 2H, H5, H9, 8.64, keto); 7.14 (s, 1H, H2, keto); 2.29 (s, 3H, H12, enol); 2.27 (s, 3H, H12, keto); 2.26 (s, 3H, H13, enol); 2.06 (s, 3H, H13, keto). ${ }^{13} \mathrm{C}-\mathrm{NMR}$ (DMSO-d 6 , $\delta$, keto, enol tautomers): 171.82 (C11, keto); 166.13 (C11, keto); 149.31 (C10, enol); 145.78 (C10, keto); 137.14 (C7, enol); 137.00 (C7, keto); 136.53 (C4, keto); 135.42 (C1, keto); 129.96 (C2, keto); 127.60 (C6, C8, enol); 127.28 (C6, C8, keto), 119.84 (C5, C9, keto); 119.70 (C5, C9, enol); 117.76 (C3, keto); 20.84 (C13, keto); 21.65 (C13, enol); 13.38 (C12, keto); 13.83 (C12, enol).

4-(Imidazole-1-yl)-acetophenone-benzoylhydrazone (4ImAcPh) (18): Yield: 92\%. White solid. M.p.: 242-243 ${ }^{\circ} \mathrm{C}$. Anal. Calc. for $\mathrm{C}_{18} \mathrm{H}_{15} \mathrm{~N}_{4} \mathrm{O}$ : C, 71.04; H, 5.30; N, 18.41. Found: C, 71.10; H, 5.47; N, 18.32\%. FW: $304.34 \mathrm{~g} \mathrm{~mol}^{-1}$. IR $\left(\mathrm{KBr}, \mathrm{cm}^{-1}\right): \mathrm{v}(\mathrm{N}-\mathrm{H}) 3139 \mathrm{~s} ; \mathrm{v}(\mathrm{C}=\mathrm{O}) 1663 \mathrm{~s} ; \mathrm{v}(\mathrm{C}=\mathrm{N}) 1614 \mathrm{~m}$. ${ }^{1} \mathrm{H}-\mathrm{NMR}\left[\mathrm{DMSO}-d_{6}, \delta, J(\mathrm{~Hz})\right]: 10.84(\mathrm{~s}, 1 \mathrm{H}, \mathrm{N} 4 \mathrm{H}) ; 8.36$ (s, 1H, H1); 7.95 (d, 2H, H6, H8, 6.36); 7.89 (d, 2H, H14, H18, 6.62); 7.83 (s, 1H, H3); 7.74 (d, 2H, H5, H9, 8.07); 7.56 (t, 3H, H15, H16, H17, 7.98); 7.14 (s, 1H, H2); 2.40 (s, 3H, H12). ${ }^{13} \mathrm{C}-\mathrm{NMR}$ (DMSO- $\left.d_{6}, \delta\right): 168.03$ (C11); 153.79 (C10); 137.37 (C7); 136.29 (C4); 135.43 (C1); 134.02 (C13); 131.23 (C16); 129.88 (C2); 128.05 (C15, C17); 127.66 (C6, C8); 127.62 (C14, C18); 117.72 (C3); 119.75 (C5, C9); 14.49 (C12).

4-(Imidazole-1-yl)acetophenone-para-chloro-benzoylhydrazone (4ImAcpClPh) (19): Yield: 96\%. White solid. M.p.: $240-243{ }^{\circ} \mathrm{C}$. Anal. Calc. for $\left(\mathrm{C}_{18} \mathrm{H}_{15} \mathrm{ClN}_{4} \mathrm{O}\right): \mathrm{C}, 63.81 ; \mathrm{H}, 4.46 ; \mathrm{N}, 16.54$. Found: C, 63.79; H, 4.38; N, 16.99\%. FW: $338.79 \mathrm{~g} \mathrm{~mol}^{-1}$. IR $\left(\mathrm{KBr}, \mathrm{cm}^{-1}\right): \mathrm{v}(\mathrm{N}-\mathrm{H}) 3240 \mathrm{~s} ; \mathrm{v}(\mathrm{C}=\mathrm{O}) 1661 \mathrm{~s}$; $v(\mathrm{C}=\mathrm{N}) 1611 \mathrm{~m} .{ }^{1} \mathrm{H}-\mathrm{NMR}$ [DMSO- $\left.d_{6}, \delta, J(\mathrm{~Hz})\right]: 10.91(\mathrm{~s}, 1 \mathrm{H}, \mathrm{N} 4 \mathrm{H}) ; 8.36(\mathrm{~s}, 1 \mathrm{H}, \mathrm{H} 1) ; 7.92(\mathrm{~m}, 4 \mathrm{H}$, H6, H8, H14, H18); 7.83 (s, 1H, H3); 7.75 (d, 2H, H5, H9, 7.60); 7.60 (d, 2H, H15, H17, 8.17); 7.14 $(\mathrm{s}, 1 \mathrm{H}, \mathrm{H} 2) ; 2.40$ (s, 3H, H12). ${ }^{13} \mathrm{C}-\mathrm{NMR}\left(\mathrm{DMSO}-d_{6}, \delta\right): 167.27$ (C11); 155.34 (C10); 141.40 (C16); 137.49 (C7); 136.19 (C4); 135.46 (C1); 132.66 (C13); 130.10 (C2); 130.01 (C6, C8); 128.27 (C15, C17); 127.86 (C14, C18); 119.76 (C5, C9); 117.76 (C3); 14.50 (C12).

4-(Imidazole-1-yl)-acetophenone-para-nitro-benzoylhydrazone (4ImAcpNO $\left.{ }_{2} P h\right)$ (20): Yield: 76\%. Yellow solid. M.p.: 279-281 ${ }^{\circ}$ C. Anal. Calc. for $\mathrm{C}_{18} \mathrm{H}_{15} \mathrm{~N}_{5} \mathrm{O}_{3}$ : C, 61.89; H, 4.33; N, 20.05. Found: C, 61.72; H, 4.28; N, 20.10\%. FW: $349.34 \mathrm{~g} \mathrm{~mol}^{-1}$. IR $\left(\mathrm{KBr}, \mathrm{cm}^{-1}\right): \mathrm{v}(\mathrm{N}-\mathrm{H}) 3136 \mathrm{~s} ; \mathrm{v}(\mathrm{C}=\mathrm{O}) 1665 \mathrm{~s}$; $v(\mathrm{C}=\mathrm{N}) 1616 \mathrm{~m}$. Due to the low solubility of the compound it was impossible to record its ${ }^{1} \mathrm{H}$ and ${ }^{13} \mathrm{C}-\mathrm{NMR}$ spectrum.

\subsection{X-ray Crystallography}

Crystals of $\operatorname{ImT} \cdot \mathrm{H}_{2} \mathrm{O}$ (1a), $\operatorname{ImTPh}$ (2), $4 \operatorname{ImBzT}$ (3), 4ImBzTM (4), 4ImBzTPh (5), 4(5) $\mathrm{Im} p \mathrm{ClPh} \cdot \mathrm{H}_{2} \mathrm{O}$ (11a), $4 \mathrm{ImBzPh}$ (14) and $4 \mathrm{ImBzpClPh}$ (15) were mounted on Mitgen loops in random orientations and used for data collection. The structures were solved by direct methods using SHELXS-97 [35] and refined by full-matrix least-squares techniques against $F^{2}$ using SHELXL-97 [36]. Positional and anisotropic atomic displacement parameters were refined for non-hydrogen atoms. Although some hydrogen atoms could be identified in a Fourier difference map, in the final model they were geometrically positioned and refined using a riding model. Molecular graphics were obtained from ORTEP [37,38]. Crystals of 11a have shown to be twinned. Moreover, the crystal structure presented disordered water molecule in four different positions with equal site occupation factor of 0.25 ; the corresponding oxygen atoms were refined isotropically. 
CCDC 903502, CCDC 952430, CCDC 903501, CCDC 952431, CCDC 952432, CCDC 903499, CCDC 952433 and CCDC 903500 contain the supplementary crystallographic data for $\mathbf{1 a}, \mathbf{2}-\mathbf{5}, \mathbf{1 1 a}$, 14 and 15, respectively. These data can be obtained free of charge via http:/www.ccdc.cam.ac.uk/ data_request/cif, or from the Cambridge Crystallographic Data Centre, 12 Union Road, Cambridge CB2 1EZ, UK; fax: +44-1223-336-033; or e-mail:deposit@ccdc.cam.ac.uk.

\subsection{Biological Assays}

Filamentous fungi, Cladosporium cladosporioides (LABB 6) and Aspergillus flavus (LABB44) were from Biotechnology and Bioassays Laboratory (LABB, Chemistry Department, Universidade Federal de Minas Gerais, Belo Horizonte, Brazil) and were maintained in potato dextrose agar (PDA) under refrigeration at $7{ }^{\circ} \mathrm{C}$. Candida glabrata (ATCC 2001) and Candida albicans (ATCC 18804) were maintained in broth heart infusion (BHI). For the experiments, fungi were grown at room temperature in PDA or BHI until abundant sporulation. Spores were harvested and suspended in sterile water, counted on a Neubauer chamber and diluted to give a suspension containing a final concentration of $5 \times 10^{3}$ spores $/ \mathrm{mL}$. An initial screening was carried out in microtiter plates, for all compounds, in duplicate, using a concentration of $100 \mu \mathrm{g} / \mathrm{well}$ (in DMSO). The final concentrations of DMSO in the assays did not exceed 2\%. Positive (inoculum plus medium) and negative (inoculum plus reference compound nystatin) controls were run simultaneously. Extracts showing activity in the screening step were also tested in the microdilution assay in 12 serial concentrations $(250,125,62.5$, $31.3,15.6,7.81,3.91,1.95,0.98,0.49,0.24$ and $0.12 \mu \mathrm{g} / \mathrm{mL}$ ), in duplicate. Fungal inhibition was assessed by using a microplate TP-reader (Thermoplate, Palm City, FL, USA). The minimum inhibitory concentration (MIC) value was defined as the lowest concentration of the compound showing $100 \%$ of fungal growth inhibition after incubation time $(48 \mathrm{~h})$. $\mathrm{MIC}_{50}$ values were assessed and express the lowest concentration of the compounds able to inhibit $50 \%$ of fungal growth. Experiments were carried out according to Zacchino and Gupta [39].

\section{Conclusions}

The imidazole-derived thiosemicarbazones were inactive against all fungi strains except for compounds $\mathbf{1}$ and $\mathbf{3}$ which proved to be selectively active against $C$. cladosporioides. In general the imidazole-derived hydrazones showed antifungal activity against $C$. glabrata and $C$. cladosporioides. Compounds 19 and 20 were selectively active against $C$. glabrata. All active compounds were more effective than the control drug nystatin. As already mentioned, selectivity is a very important property of an antifungal, which allows an optimum exploitation of its capacity without affecting beneficiating microorganisms. Hence, some of the studied compounds could constitute novel antifungal drug candidate prototypes.

\section{Supplementary Materials}

Supplementary materials can be accessed at: http:/www.mdpi.com/1420-3049/18/10/12645/s1. 


\section{Acknowledgments}

This work was supported by PNPD-CAPES, CNPq and INCT-INOFAR (Proc. CNPq 988573.364/2008-6) from Brazil.

\section{Conflicts of Interest}

The authors declare no conflict of interest.

\section{References}

1. Bell, A.S. Triazole antifungals: Itraconazole (Sporanox), fluconazole (Diflucan), Voriconazole (Vfend) and fosfluconazole (Prodif). In The Art of Drug Synthesis; Jonhson, D.S., Li, J.J., Eds.; John Wiley \& Sons, Inc.: Hoboken, NJ, USA, 2007; pp. 72-73.

2. Narasimhan, B.; Sharma, D.; Kumar, P. Biological importance of the imidazole nucleus in the new millennium. Med. Chem. Res. 2011, 20, 1119-1140.

3. Melander, C.; Cavanagh, J.; Ritchie, D.F.; Rogers, S.A.; Robert, W. Inhibition and dispersion of biofilms in plants with imidazole-triazole derivatives. WIPO Patent 2010077603, 8 July 2010.

4. Dumeunier, R.; Lamberth, C.; Trah, S. Imidazole derivatives. WIPO Patent 2010102866, 10 September 2010.

5. Takemoto, J.Y.; Bensaci, M.; De Lucca, A.J.; Cleveland, T.E.; Gandhi, N.R.; Skebba, V.P. Inhibition of Fungi from Diseased Grape by Syringomycin E-Rhamnolipid Mixture. Am. J. Enol. Vitic. 2010, 61, 210-214.

6. Pitt, J.I.; Hocking, A.D.; Bhudhasamai, K.; Miscamble, B.F.; Wheeler, K.A.; Tanboon-Ek, P. The normal mycoflora of commodities from Thailand. 2. Beans, rice, small grains and other commodities. Int. J. Food Microbiol. 1994, 23, 35-43.

7. Sveistyte, L.; Lugauskas, A.; Vidgiryte, A. Potential toxin producing micromycetes in the dust of mills and agricultural production storehouse. Bot. Lith. 2005, 11, 179-189.

8. Lugauskas, A.; Krikstaponis, A.; Sveistyte, L. Airborne fungi in industrial environments-potential agents of respiratory diseases. Ann. Agric. Environ. Med. 2004, 11, 19-25.

9. Gugnani, H.C.; Gupta, S.; Talwar, R.S. Role of opportunistic fungi in ocular infections in Nigeria. Mycopathologia 1978, 65, 155-166.

10. Vesper, S.J.; Rogers, M.E.; Neely, A.N.; Haugland, R.A. Opportunistic Aspergillus. pathogens measured in home and hospital tap water by quantitative PCR (QCPR). J. Water Health 2007, 5, 427-431.

11. Pervez, H.; Iqbal, M.S.; Tahir, M.Y.; Nasim, F.; Choudhary, M.I.; Khan, K.M. In vitro cytotoxic, antibacterial, antifungal and urease inhibitory activities of some N4- substituted isatin-3thiosemicarbazones. J. Enzym. Inhib. Med. Chem. 2008, 23, 848-854.

12. Beraldo, H.; Gambino, D. The wide pharmacological versatility of semicarbazones, thiosemicarbazones and their metal complexes. Min. Rev. Med. Chem. 2004, 4, 159-165.

13. Rollas, S.; Küçükgüzel, Ş.G. Biological activities of hydrazone derivatives. Molecules 2007, 12, 1910-1939. 
14. Khalil, S.M.E.; Shebl, M.; Al-Gohani, F.S. Zinc(II) thiosemicarbazone complex as a ligand towards some transition metal ions: synthesis, spectroscopic and antimicrobial studies. Acta Chim. Slov. 2010, 57, 716-725.

15. Despaigne, A.A.R.; Vieira. L.F.; Mendes, I.C.; Costa, F.B.; Speziali, N.L.; Beraldo, H. Organotin(iv) complexes with 2-acetylpyridine benzoyl hydrazones: Antimicrobial activity. J. Braz. Chem. Soc. 2010, 21, 1247-1257.

16. Parrilha, G.L.; Da Silva, J.G.; Gouveia, L.F.; Gasparoto, A.K.; Dias, R.P.; Rocha, W.R.; Santos, D.A.; Speziali, N.L.; Beraldo, H. Pyridine-derived thiosemicarbazones and their tin(IV) complexes with antifungal activity against Candida spp. Eur. J. Med. Chem. 2011, 46, 1473-1482.

17. Özdemir, A.; Turan-Zitouni, G.; Kaplancikli A.Z.; Demirci, F.; Iscan, G. Studies on hydrazone derivatives as antifungal agents. J. Enzym. Inhib. Med. Chem. 2008, 23, 470-475.

18. Kaplancikli, Z.A.; Turan-Zitouni, G.; Özdemir, A.; Revial, G. Synthesis and anticandidal activity of some imidazopyridine derivatives. J. Enzym. Inhib. Med. Chem. 2008, 23, 866-870.

19. Reis, D.C.; Pinto, M.C.X.; Souza-Fagundes, E.M.; Wardell, S.M.S.V.; Wardell, J.L.; Beraldo, H. Antimony(III) complexes with 2-benzoylpyridine-derived thiosemicarbazones: Cytotoxicity against human leukemia cell lines. Eur. J. Med. Chem. 2010, 45, 3904-3910.

20. Casas, J.S.; Castiñeiras, A.; Rodríguez-Argüelles, M.C.; Sánchez, A.; Sordo, J.; Vázquez-López, A.; Vázquez-López, E. Diorganotin(IV) complexes of imidazole-2-carbaldehyde thiosemicarbazone (H2ImTSC). The crystal and molecular structures of the "free" ligand and of [ $\left.\mathrm{SnMe}_{2}(\mathrm{ImTSC})\right]$. J. Chem. Soc. Dalton Trans. 2000, 14, 2267-2272.

21. Bastos, M.A.B.; Alcântara, A.F.C.; Beraldo, H. Structural analyses of 4-benzoylpyridine thiosemicarbazone using NMR techniques and theoretical calculations. Tetrahedron 2005, 61, 7045-7053.

22. Singh, S.; Bharti, N.; Naqvi, F.; Azam, A. Synthesis, characterization and in vitro Antiamoebic Activity of 5-nitrothiophene-2-carboxaldehyde thiosemicarbazones and their Palladium(II) and Ruthenium(II) Complexes. Eur. J. Med. Chem. 2004, 39, 459-465.

23. Beraldo, H.; Nacif, W.F.; West, D.X. Spectral studies of semicarbazones derived from 3- and 4formylpyridine and 3- and 4-acetylpyridine: Crystal and molecular structure of 3-formylpyridine semicarbazone. Spectrochim. Acta Pt. A-Mol. Bio. 2001, 57, 1847-1854.

24. Alonso, R.; Bermejo, E.; Carballo, R.; Castineiras, A.; Pérez, T. The supramolecular chemistry of thiosemicarbazones derived from pyrrole: a structure view. J. Mol. Struc. 2002, 606, 155-173.

25. Ferraz, K.S.O.; Silva, N.F.; Da Silva, J.G.; Speziali, N.L.; Mendes, I.C.; Beraldo, H. Structural studies on acetophenone- and benzophenone-derived thiosemicarbazones and their zinc(II) complexes. J. Mol. Struc. 2012, 1008, 102-107.

26. Soares, M.A.; Lessa, J.A.; Mendes, I.C.; Da Silva, J.G.; dos Santos, R.G.; Salum, L.B.; Daghestani, H.; Andricopulo, A.D.; Day, B.W.; Vogt, A.; et al. $N^{4}$-Phenyl-substituted 2-acetylpyridine thiosemicarbazones: Cytotoxicity against human tumor cells, structure-activity relationship studies and investigation on the mechanism of action. Bioorg. Med. Chem. 2012, 20, 3396-3409.

27. Lessa, J.A.; Reis, D.C.; Mendes, I.C.; Speziali, N.L.; Rocha, L.F.; Pereira, V.R.A.; Melo, C.M.L.; Beraldo, H. Antimony(III) complexes with pyridine-derived thiosemicarbazones: Structural studies and investigation on the antitrypanosomal activity. Polyhedron 2011, 30, 372-380. 
28. Costa, R.F.F.; Rebolledo, A.P.; Matencio, T.; Calado, H.D.R.; Ardisson, J.D.; Cortes, M.E.; Rodrigues, B.L.; Beraldo, H. Metal complexes of 2-Benzoylpyridine-derived thiosemicarbazones: Structural, electrochemical and biological studies. J. Coord. Chem. 2005, 58, 1307-1319.

29. Ray, A.; Banerjee, S.; Sen, S.; Butcher, R.J.; Rosair, G.M.; Garland, M.T.; Mitra, S. Two Zn(II) and one $\mathrm{Mn}(\mathrm{II})$ complexes using two different hydrazone ligands: spectroscopic studies and structural aspects. Struct. Chem. 2008, 19, 209-217.

30. Despaigne, A.A.R.; Parrilha, G.L.; Izidoro, J.B.; da Costa, P.R.; dos Santos, R.G.; Piro, O.E.; Castellano, E.E.; Rocha, W.R.; Beraldo, H. 2-Acetylpyridine- and 2-benzoylpyridine-derived hydrazones and their gallium(III) complexes are highly cytotoxic to glioma cells. Eur. J. Med. Chem. 2012, 50, 163-172.

31. Rebolledo, A.P.; Vieites, M.; Gambino, D.; Piro, O.E.; Castellano, E.E.; Zani, C.L.; Fagundes, E.M.S.; Teixeira, L.R.; Batista, A.A.; Beraldo, H. Palladium(II) complexes of 2-benzoylpyridine-derived thiosemicarbazones: spectral characterization, structural studies and cytotoxic activity. J. Inorg. Biochem. 2005, 99, 698-706.

32. Graminha, A.E.; Rodrigues, C.; Batista, A.A.; Teixeira, L.R.; Fagundes, E.S.; Beraldo, H. Ruthenium(II) complexes of 2-benzoylpyridine-derived thiosemicarbazones with cytotoxic activity against human tumor cell lines. Spectrochim. Acta Pt. A-Mol. Bio. 2008, 69, 1073-1076.

33. Despaigne, A.A.R.; Da Silva, J.G.; Carmo, A.C. M.; Sives, F.; Piro, O.E.; Castellano, E.E.; Beraldo, H. Copper(II) and zinc(II) complexes with 2-formylpyridine-derived hydrazones. Polyhedron 2009, 28, 3797-3803.

34. CrysAlis RED, Version 1.171.32.38.SCALE3 ABSPACK scaling algorithm; Oxford Diffraction Ltd.: Abingdon, England, UK, 2006.

35. Sheldrick, G.M. SHELXS-97; Program for Solution of Crystal Structures, University of Göettingen, Göettingen, Germany, 1997.

36. Sheldrick, G.M. SHELXL-97; Program for Crystal Structures Analysis, University of Göettingen, Germany, 1997.

37. Farrugia, L.J. WinGX suite for small-molecule single-crystal crystallography. J. Appl. Cryst. 1999, 32, 837-838.

38. Farrugia, L.J. ORTEP-3 for Windows-A version of ORTEP-III with a Graphical User Interface (GUI). J. Appl. Cryst. 1997, 30, 565.

39. Visbal, G.; San-Blas, G. Esteroles de hongos y parásitos por cormatografía de gases y espectrometría de masas. In Manual de Técnicas in vitro Para la Detección de Compuestos Antifúngicos; Zacchino, S.A.; Gupta, M.P., Eds.; Corpus Editorial: Rosario, Argentina, 2007; pp. 95-99.

Sample Availability: Samples of all hydrazones and thiosemicarbazones are available from the authors.

(C) 2013 by the authors; licensee MDPI, Basel, Switzerland. This article is an open access article distributed under the terms and conditions of the Creative Commons Attribution license (http://creativecommons.org/licenses/by/3.0/). 